\title{
CONSIDERAŢI PRELIMINARE ASUPRA UNEI INCINTE FUNERARE DIN NECROPOLA ROMANĂ DE INCINERATIE DIN PUNCTUL TĂUL HOP-GĂURI (ROŞIA MONTANĂ, JUD. ALBA)
}

\author{
Ionuţ Bocan, Cătălina-Mihaela Neagu \\ Emil lonuţ Dumitraşcu, Gabriel Bălan
}

\begin{abstract}
PRELIMINARY CONSIDERATIONS ABOUT ONE FUNERARY PRECINCT FROM A CREMATION ROMAN NECROPOLIS FROM THE SITE TÃUl HOP-GĂURI (ROŞIA MONTANĂ, ALBA COUNTY)
\end{abstract}

In 2002 was investigated, in the framework of the "Alburnus Maior National Research Program", a rectangular funerary precinct with two functioning phases; its dimensions are $5.40 \times 5.00 \times 4.80 \times 4.64 \mathrm{~m}$. (the first phase), and $8.16 \times 7.92 \times 7.20 \times 6.40 \mathrm{~m}$. (the second phase). The funerary precinct is part of the Roman cremation necropolis from Tăul Găuri-Hop site. Inside the funerary structure, four cremation graves were identified and researched, all of them belonging to the general type of graves in this necropolis. Also have been identified four pits which indicate human interventions on the four graves inside the precinct. The funerary inventory is characteristic for the necropolises at Aburnus Maior: pottery and metal objects. The entire complex was dated to the $2^{\text {nd }}$ century A.D.

Key words: funerary precinct, cremation graves, necropolis, funerary inventory, intervention pits.

Cuvinte cheic: incintă funerară. morminte de incineraţie, necropolă, inventar funerar, gropi de intervenţie.

\section{Introducere'}

Cercetările arheologice efectuate la Roşia Montană între anii 2001-2006, în cadrul Programului Naţional de Cercetare Alburnus Maior, au scos la lumină cinci necropole de incineraţie şi două zone funerare. În cadrul acestora au fost descoperite şi cercetate mai multe incinte funcrare ${ }^{2}$.

Acest studiu preliminar ${ }^{3}$ este dedicat analizei unei incinte funerare din necropola romană de incineraţie de la Tăul Găuri-Hop',

\footnotetext{
'I.ista abrevierilor utilizate în text: ad. = adâncimea gropii: ad. treaptă $=$ adâncimea pe treaptā: cca. = circa: $\mathrm{M}=$ mormânt. $\mathrm{db}=$ dianctrul bazei: $\mathrm{dg}=$ diametrul gură: dmax $=$ diametrul maxim: gr $=$ grosime: gr.pr. = grosimea perelclui: $h=$ inālp̧inca: $h p=$ înălţimea pāstrată: $H_{p} .=$ ināḷimea zidului păstrat: $L$ = lungimea; $I$ = lălimea: $L$,cui = lungimea cui: $L_{p}=$ lungimea pāstrată: nr. inv. pr. = număr de inventar provizoriu: pl. = planşă.

? Veyi infira notele 17-20.

'Textul sludiului este redactat de Ionut Bocan şi CălălinaMihacla Neagu.

1 Punctul IIop-Găuri este localizal la sud de drumul lorestier care străbate proprictated Lxploatării Miniere Roșia Montană. limita de nord liind constituită de masivul Cetale. cu reperul lix pe care il reprezintă punctul
}

perimetru cercetat ${ }^{5}$, în campaniile arheologice din anii 2001-2002 ${ }^{6}$.

Obiectivul arheologic analizat în acest studiu se doreşte a fi o continuare a publicării incintelor funerare de la Roşia Montană, completând totodată, studiul realizat în anul 2008 asupra unei incinte funerare din necropola romană de incineraţie de la Tăul Secuilor-Pârâul Porcului?.

În campania de cercetare arheologică din anul $2002^{8}$ a fost identificată şi cercetată o incintă funerară. Ansamblul funerar este

topogralic Găuri. Denumirea zonei se releră la două coline situate la sud-vest de terasa denumilă Găuri: la baza colinei vestice. spre sud, se allă un lac artilicial, ce poartă denumirea de Tāul Găuri.

5 Se cuvine mentionat faptul că în acest punct au fost cercetate urme de extraçie a minereului aurifer, datate in perioada romană de către colectivul de arheologi minieri al Universitălii Toulouse - Le Mirail.

${ }^{6}$ Alburnus Maior I, 193-251: CCA 2003, 104-105.

${ }^{7}$ Neagu, Bocan 2007-2008. 93-122.

${ }^{8}$ Colectivul de cercetare a fost lormat din: Paul Damian. Mihacla Simion. Gabricl Bālan. L̇mil Dumitraşcu. CălālinaMihacla Neagu, Decebal Vlẹja. 
amplasat în partea de nord-est a perimetrului cercetat din necropola de la Tăul Găuri-Hop, în unităłile de săpătură cu siglele S 002, S 003, S 004, S 007, S 009 şi S 010 (Pl. 1).

Ansamblul funerar are două faze de construcţie, patru înmormântări şi patru gropi de intervenție. Construcţia este orientată pe axa ENE-VSV. În prima fază de funcţionare incinta are dimensiunile de 5,40 ×5,00 ×4,80 ×4,64 m, iar în cea de-a doua fază de $8,16 \times 7,92 \times 7,20 \times$ 6,40 m (Pl. 2)".

\section{Caracteristici stratigrafice (PI. 3)}

Stratigrafia generală a ansamblului funcrar:

I. Sol vegetal de culoare cenuşie (orizontul organic al solului actual), cu o grosime variabilă de la 0,08 la $0,46 \mathrm{~m}$; nisipos, omogenitate slabă; are în compoziţie pietriş, resturi vegetale şi organice.

II. Nivel de argilă siltică brun negriciosă cu o grosime de la 0,06 la $0,84 \mathrm{~m}$; în compoziţie s-au putut observa fragmente de rocă demineralizată, fragmente ccramice de factură romană, pigmenţi de cărbune şi de sol ars.

III. Nivel de argilă siltică, de culoare galben-lutos, nisipos, compact, are în compoziţie fragmente de şisturi argiloase, oxizi de fier, pigmenţi de cărbune, sol ars. Sedimentul are variafii de ordin cromatic de la galben-deschis la galben-roşcat, cu grosimi variabile, pe adâncimi, de la $-0,38 \mathrm{~m}$ la $-0,70 \mathrm{~m}$, compact, conţine rare granule de pietriş, concentraf̧ii de oxizi de fier, cuart, fragmente de sol ars, fragmente ceramice de factură romană (poziţionate la partea superioară a nivelului), pigmenţi de cărbune; gropile mormintelor M 30 şi M 31 sunt săpate în acest nivel, partea inferioară a mormintelor fiind săpată în stâncă.

Din punct de vedere stratigrafic sedimentul de umplutură a gropii este de culoare galben-maronic, conţine pietre de dimensiuni medii, fragmente de sol ars de culoare roşiatică.

Caracteristici constructive (PI. 2)

În cursul cercetării au fost identificate trasecle a opt ziduri, corespunzătoare celor două faze de functionare a incintei funerare. Acestea

\footnotetext{
"Ridicarcà topogralicãa a fost realizată de Virgil Apostol.
}

au fost denumite convenţional $\mathbf{Z 1}$ (faza II), $\mathbf{Z 2}$ (faza II), Z1a (faza I), Z2a (faza I), Z3 (faza I), Z4 (faza I), Z5 (faza II), Z6 (faza II) ${ }^{10}$.

Z1a: amplasat în S 004 şi S 010; construit din blocuri de piatră nefasonate de dimensiuni medii, având ca liant pământ; orientat: NNESSV; dimensiuni: $L=5,00 \mathrm{~m} ; \mathrm{I}=0,44-0,60 \mathrm{~m}$; $\mathrm{Hp}=0,82 \mathrm{~m}$. Se păstrează pe înălţimea a şapte asize. Era vizibil şanţul de fundaţie, cu o lăţime de cca. $0,80 \mathrm{~m}$ şi o adâncime de cca. $0,20-0,30$ $\mathrm{m}$.

Z2a: amplasat în S 009 şi S 010; construit din blocuri de piatră nefasonate, având ca liant pământ; orientat: VNV-ESE; dimensiuni: L = $4,80 \mathrm{~m} ; \mathrm{l}=0,40-0,52 \mathrm{~m} ; \mathrm{Hp}=0,36 \mathrm{~m}$; zidul se păstrează pe înălţimea a două asize. A fost identificată o bază de monument funerar, poziffionată central, la nivelul acestui zid, probabil utilizată în prima fază de funcţionare a incintei (peste acest element de arhitectură au mai fost adăugate doua asize în cea de-a doua fază de funcţionare a incintei). Sanţul de fundaţie are dimensiuni de cca. $0,65 \mathrm{~m}$ lăţime şi o adâncime de cca. $0,20 \mathrm{~m}$.

Z3: amplasat în $\mathrm{S} 009$; construit din blocuri de piatră nefasonate, având ca liant pământ; orientat: NNE-SSV; dimensiuni: L = $4,64 \mathrm{~m} ; \mathrm{l}=0,40-0,56 \mathrm{~m} ; \mathrm{Hp}=0,32 \mathrm{~m}$. Zidul a fost demantelat în faza a doua de funcţionare a incintei, odată cu extinderea acesteia. A fost surprins pe înălţimea a două asize; este demantelat până la ultimele două asize, probabil, în urma extinderii incintei în faza a doua de funcţionare. Zidul este suprapus de mormântul M 30, fiind utilizat la amenajarea laturii de vest a acestui complex funerar. Şanţul de fundaţie are dimensiuni de cca. $0,65 \mathrm{~m}$ lăţime şi o adâncime de cca. $0,20-0,30 \mathrm{~m}$.

Z4: amplasat în S 003 şi S 004; construit din blocuri de piatră nefasonate, având ca liant pământ; orientat: VNV-ESE; dimensiuni: L = $5,40 \mathrm{~m} ; \mathrm{l}=0,40 \mathrm{~m} ; \mathrm{Hp}=0,42 \mathrm{~m}$. Zidul se păstrează pe trei asize, pe o lungime de $1,72 \mathrm{~m}$, din restul traseului fiind surprinsă doar amprenta (,în negativ"); a fost demantelat până la ultimele trei asize în faza a doua de funcţionare a incintei,

10 Zidurile au fost numerotate în ordinca apariţiei şi cercetării lor. 
odată cu extinderea acesteia. O parte din zid a fost scoasă în totalitate datorită amenajării mormântului $M$ 32. Şanţul de fundaţie are dimensiuni de cca. $0,50 \mathrm{~m}$ lăţime şi o adâncime de cca. $0,20-0,30 \mathrm{~m}$.

Z1: amplasal în S 004 şi S 010 ; construit din blocuri de piatră fasonate şi nefasonate, având ca liant pământ; orientat: NNE-SSV; dimensiuni: $\mathrm{L}=7,20 \mathrm{~m} ; \mathrm{l}=0,44-0,60 \mathrm{~m} ; \mathrm{Hp}=$ $0,54-0,82 \mathrm{~m}$; zidul a fost construit prin extinderea, cu $2,20 \mathrm{~m}$ spre nord a zidului $\mathbf{Z 1 a}$, fiind surprins pe înălţimea a trei asize, respectiv şapte, pentru a asigura planeitate spaţiului funcrar consacrat. Sanţul de fundaţie are dimensiuni de cca. $0,80 \mathrm{~m}$ lătime şi o adâncime de cca. $0,20-0,30 \mathrm{~m}$.

Z2: amplasat în S 007, S 009 şi S 010; construit din blocuri de piatră nefasonate, având ca liant pământ; orientat: VNV-ESE; dimensiuni: $\mathrm{I} .=7.92 \mathrm{~m} ; \mathrm{l}=0,40-0,64 \mathrm{~m}$; Hp = 0,56 m; zidul a fost construit prin extinderea, cu 3,12 $\mathrm{m}$ spre est a zidului $\mathbf{Z 2 a}$ şi prin înălţarea acestuia cu două asize, fiind surprins pe înălţimea a patru asize. Ultima asiză a fost construită, probabil, din blocuri de piatră fasonate într-o manieră particulară, respectiv sub forma unor capace în două ape (chaperon). Din acestea s-a păstrat un singur capac, cu dimensiunile de cca. $0,80 \times 0,48$ $\times 0.20 \mathrm{~m}$. Sanţul de fundaţie are dimensiuni de cca. $0,60 \mathrm{~m}$ lăţime şi o adâncime de cca. $0,16 \mathrm{~m}$.

Z5: amplasat în S 002 şi S 007; construit din blocuri de piatră nefasonate de dimensiuni medii, având ca liant pământ; orientat: NNESSV; dimensiuni: $L=8,16 \mathrm{~m} ; \mathrm{I}=0,68 \mathrm{~m} ; \mathrm{Hp}=$ $0,48-0,80 \mathrm{~m}$; se păstrează pe înălţimea a trei asize. Şanful de fundaţie are dimensiuni de cca. $0,90 \mathrm{~m}$ lăţime şi o adâncime de cca. 0,20-0,30 m.

Z6: amplasat în S 002, S 003 şi S 004; construit din blocuri de piatră nefasonate, de dimensiuni medii, având ca liant pământ; orientat: VNV-ESE; dimensiuni: $\mathrm{L}=6,40 \mathrm{~m} ; \mathrm{l}=$ $0,56 \mathrm{~m} ; \mathrm{H}=0.88 \mathrm{~m}$; zidul este construit pe înălţimea a cinci asize. Ultima asiză a fost construită, probabil, din blocuri de piatră fasonate într-o manieră particulară, respectiv sub forma unor capace în două ape (chaperon). Se păstrează opt fragımente. Şanţul de fundaţie, săpat în stâncă, are dimensiuni de cca. $1,04 \mathrm{~m}$ lăţime şi o adâncime de cca. 0,22-0,32 m.

Pe baza acestor considerente am putut distinge două faze de funcţionare a incintei funerare. De fapt, este vorba despre o construcţie iniţială, descrisă de Z1a (zidul de vest), Z2a (zidul de sud), $\mathbf{Z 3}$ (zidul de est) şi $\mathbf{Z 4}$ (zidul de nord). În această fază construcţia are o suprafaţă de $24,46 \mathrm{~m}^{2}$ şi adăposteşte un complex funerar (M 31 ).

Cea de-a doua fază constructivă, descrisă de $\mathbf{Z 1}$ (zidul de vest), $\mathbf{Z 2}$ (zidul de sud), $\mathbf{Z 5}$ (zidul de est), Z6 (zidul de nord), este, mai degrabă, o extindere a incintei atât spre nord, cât şi spre est, cu $30,11 \mathrm{~m}^{2}$, probabil din necesităţi legate de extinderea spaţiului funerar consacrat. $\mathbf{Z 3}$ (zidul de est) şi $\mathbf{Z 4}$ (zidul de nord) sunt parţial dezafectate, în timp ce funcţionalitatea zidurilor de vest şi de sud, din prima fază de construcţie (Z1a și Z2a) este păstrată, fiind extinse spre nord, respectiv spre est ${ }^{\prime \prime}$, astfel încât în faza a doua de funcţionare incinta funerară are o suprafaţă de $54,57 \mathrm{~m}^{2}$.

\section{Descrierea mormintelor:}

În interiorul ansamblului funerar au fost identificate şi cercetate patru morminte de incineraţie (M 29, M 30, M 31, M 32) ${ }^{12}$. Toate cele patru gropi sepulcrale au suferit perturbări antropice (G 1, G 2, G 3, G 4).

\section{MORMÂNT NR. 29 (Pl. 4)}

ardere pe loc

Localizare: secţiunea S 002, caroul 5.

Groapă de formă rectangulară, cu pereţii uşor evazaţi, secţiune trapezoidală, fundul plat. L $=1,72 \mathrm{~m}, 1=0,96 \mathrm{~m}$, ad. $=0,75 \mathrm{~m}$; orientare: VNV-ESE. Groapa, arsă (arsură discontinuă de $0,04 \mathrm{~m}$ ) este săpată în stâncă. În jurul mormântului stânca prezenta urme de ardere. Mormântul a fost amenajat pe o platformă construită în stâncă.

Fragmentele de oase calcinate sunt dispuse în partea inferioară a gropii, compact, fără nici o operaţiune de separare a acestora de resturile

\footnotetext{
"I În faza a doua de funcţionare a incintei Z1a a fost extins cu 2.20 in spre nord, iar Z2a cu 3.12 m spre est.

${ }_{12}$ Numerolarea mormintelor este unitară cu siglele utilizate in restul necropolei.
} 
rugului (depunere uniformă de cărbune de lemn, fragmente de bârne carbonizate în amestec cu fragmente de oase calcinate; grosimea acestui strat este de $0,10-0,19 \mathrm{~m})$. Groapa sepulcrală este puternic afectată de o intervenţie antropică (G1).

Inventar funerar: ceramică: un urcior, trei oale, trei cupe, două opaiţe; fier: o scoabă, un piron.

\section{Urcior nedeterminabil ca tip ${ }^{13}$} (fragmentar. se păstrează baza cu corp); db = 4 $\mathrm{cm} ; \mathrm{hp}=3.2 \mathrm{~cm}$. Pastă RM $3^{14}$. Ardere primară uniformă. Puternic afectată de aciditatea solului. Bază inelară. Nr. inv. pr. TGH 159. Pl. 5/1

2. Oală nedeterminabilă ca tip (fragment din buză); dg = $15 \mathrm{~cm}$; hp = 2,1 cm. Pastă RM I. Ardere primară uniformă. Uşor afectată de aciditatea solului. Buză rotunjită, îngroşată. Nr. inv. pr. TGH 160. PI. 5/2

\section{Oală nedeterminabilă ca tip} (fragmentară, se păstrează un fragment de bază cu corp şi trei fragmente din corp); $d b=9 \mathrm{~cm}$; hp $=3,8 \mathrm{~cm}$. Pastă RM 6. Ardere primară uniformă. Urme de ardere secundară pe interior. Bază dreaptă. Corp decorat cu două caneluri. Nr. inv. pr. TGH 161. Pl. 5/3

4. Oală nedeterminabilă ca tip (fragment din bază cu corp); db = $10 \mathrm{~cm} ; \mathrm{hp}=2 \mathrm{~cm}$. Pastă RM 16. Ardere primară incompletă. Bază dreaptă. Nr. inv. pr. TGH 162. PI. 5/4

5. Cupă nedeterminabilă ca tip, imitaţie de vas cu pereţi fini (întregibilă, se păstrează două fragmente din buză cu corp, douã din toartă, două din bază cu corp şi 16 fragmente corp); $\mathrm{dg}=8,3 \mathrm{~cm} ; \mathrm{db}=6,4 \mathrm{~cm}$; hestimativ $=10$ $\mathrm{cm}$; gr.pr. $=3 \mathrm{~mm}$. Pastă RM 14. Ardere primară uniformă. Ardere secundară. Afectată de aciditatea solului. Buză uşor înclinată spre exterior, rotunjită. Bază inelară. Este prevăzută cu o toartă necanelată, ataşată sub buză. Nr. inv. pr. TGH 163. Pl. 5/5

\footnotetext{
1.3 Detenminarea fonmelor a lost realizată prin încadrarea în tipologia generala a ceramicii descoperită în necropola de incincrạtie de la Tăul Coma, realizată de un colectiv de cercetare format din Viorica Rusu-Bolindeł Adela Bâltâc, Ionụ Bocan şi Mariana Egri —cf. Albumus Maior III 2008, 35-68.

It Pastele au fost incadrate în codurile de paste. stabilite pentru lotul cerampic din necropola de incineraţie de la Tăul Corma-cf. Alburnus Maior IlI 2008, 69 si Pl. 336.
}

6. Cupă nedeterminabilă ca tip, imitaţie de vas cu pereţi fini (fragment din buză cu corp); $\mathrm{dg}=8 \mathrm{~cm} ; \mathrm{hp}=2,8 \mathrm{~cm} ;$ gr.pr. $=3 \mathrm{~mm}$. Pastă RM 7. Ardere primară uniformă. Puternic arsă secundar. Buză înclinată spre exterior, detaşată, rotunjită. Nr. inv. pr. TGH 164. PI. 5/6

7. Cupă nedeterminabilă ca tip, imitaţie de vas cu pereţi fini (fragment din bază); $d b=3$ cm; hp = $1 \mathrm{~cm} ;$ gr.pr. $=2 \mathrm{~mm}$. Pastă RM 5. Ardere primară uniformă. Puternic afectată de aciditatea solului. Bază inelară. Nr. inv. pr. TGH 165. Pl. $5 / 7$

\section{Opait nedeterminabil ca tip} (fragmentar, se păstrează patru fragmente din bordură, trei din partea inferioară a ciocului şi opt din rezervor, cu dimensiuni cuprinse între l$3 \mathrm{~cm}$ ). Pastă RM 3. Ardere primară uniformă. Puternic afectată de aciditatea solului. Bordură îngustă, prevăzută cu trei butoni. Rezervor tronconic (?). Nr. inv. pr. TGH 166. PI. 5/8

9. Opaiţ nedeterminabil ca tip (fragmentar, se păstrează ansa); $d$ ansă $=2,3 \mathrm{~cm}$. Pastă RM 8. Ardere primară uniformă. Ansă inelară. Nr. inv. pr. TGH 167. Pl. 5/9

10. Scoabă (fragmentară); $L p=1,5 \mathrm{~cm}$. Fier oxidat, corodat. Un cui rupt, celălalt păstrat în întregime: Lcui $=5 \mathrm{~cm}$. Bară parţial păstrată, afectată de coroziune, cu secţiune pătrată: $0,8 \mathrm{~cm}$. Nr. inv. pr. TGH 168. Pl. 5/10

11. Piron (fragmentar); $\mathrm{Lp}=11 \mathrm{~cm}$. Fier oxidat, corodat. Cap rotund, bombat. Corp parţial păstrat, puternic îndoit, cu secţiune pătrată: 0,8 cın. Vârf rupt. Nr. inv. pr. TGH 169. PI. 5/11

\section{MORMÂNT NR. 30 (PI. 6)}

ardere pe loc

Localizare: secţiunea S 002, caroul 6.

Groapă cu treaptă; etaj superior cu secţiune trapezoidală; etajul inferior de formă rectangulară, cu pereţii uşor evazaţi; fundul plat. Etajul superior: $\mathrm{L}=2,47 \mathrm{~m} ; \mathrm{I}=2,46 \mathrm{~m}$. Etajul inferior: $\mathrm{L}=1,88 \mathrm{~m} ; \mathrm{I}=1,00 \mathrm{~m}$; ad. treaptă = $0,80 \mathrm{~m} ; \mathrm{ad} .=1,13 \mathrm{~m}$. Groapa, arsă (arsură continuă de $0,04 \mathrm{~m}$ ) este săpată în parte superioară în pământ, iar partea inferioară în stâncă; orientare: VNV-ESE. Etajul superior al 
gropii este amenajat peste zidul $\mathbf{Z 3}$ pentru a conferii planeitate amenajării gropii sepulcrale.

Fragmentele de oase calcinate sunt dispuse în partea inferioară a gropii, compact, fără nici o operaţiune de separare a acestora de resturile rugului (depunere uniformă de cărbune de lemn, fragmente de bârne carbonizate în amestec cu fragmente de oase calcinate; grosimea acestui strat este de $0,06-0,12 \mathrm{~m}$ ). Groapa sepulcrală este puternic afectată de o intervenţie antropică (G2).

Inventar funerar: ceramică: un urcior, patru turibula, două oale, o farfurie, un opaiţ, un vas nedeterminabil ca formă; bronz: o monedă; ficr: un piron.

\section{Urcior (?) nedeterminabil ca tip} (fragmentar, se păstrează nouă fragmente din corp, cu dimensiuni cuprinse între 1,6-4,5 cm). Pastă RM 8. Ardere primară uniformă. Uşor afectată de aciditatea solului. Demarcaţia dintre gât şi corp este realizată prin două caneluri fine. Nr. inv. pr. TGH 170.

2. Turibulum de tip T 5.6 (întregit); $\mathrm{dg}=22$ $\mathrm{cm} ; \mathrm{db}=9,8 \mathrm{~cm} ; \mathrm{h}=15,2 \mathrm{~cm}$. Pastă RM 1. Ardere primară incompletă. Ardere secundară la interior şi cxterior. Urme de substanţă organică pe bază. Nr. inv. pr. TGH 171. Pl. 7/2

3. Turibulum de tip $\mathbf{T} 5.6$ (întregit); $\mathrm{dg}=$ $20,4 \mathrm{~cm} ; \mathrm{db}=8,8 \mathrm{~cm} ; \mathrm{h}=16,5 \mathrm{~cm}$. Pastă $\mathrm{RM}$ 10. Ardere primară uniformă. Ardere secundară pe interior, provenită, probabil, în urma utilizării. Nr. inv. pr. TGH 172. Pl. 7/3

4. Turibulum de tip T 5.6 (întregit); $\mathrm{dg}=$ $20 \mathrm{~cm} ; \mathrm{db}=9,8 \mathrm{~cm} ; \mathrm{h}=15 \mathrm{~cm}$. Pastă RM 10. Ardere primară uniformă. Ardere secundară pe interior, provenită, probabil, în urma utilizării. Nr. inv. pr. 'TGH 173. Pl. 8/4

5. Turibulum nedeterminabil ca tip (fragment din buză); $d g=22,6 \mathrm{~cm} ; \mathrm{hp}=2,7 \mathrm{~cm}$. Pastă RM 6. Ardere primară uniformă. Ardere secundară la interior. Buză uşor înclinată spre exterior, decorată cu alveole mari, realizate prin presarea cu degetele a celor două margini ale buzei când pasta este crudă. Nr. inv. pr. TGH 174. PI. $8 / 5$

\section{Oală nedeterminabilă ca tip} (fragmentară, se păstrează un fragıment din bază cu corp şi un fragment din corp); db $=6,1 \mathrm{~cm}$; $h p=2,5 \mathrm{~cm}$. Pastă RM 16. Ardere primară uniformă. Ardere secundară la exterior. Bază dreaptă. Nr. inv. pr. TGH 175. Pl. 8/6

7. Oală nedeterminabilă ca tip (fragmentară, se păstrează un fragment din bază cu corp şi patru fragmente din corp); $d b=6,2 \mathrm{~cm}$. Pastă RM 10. Ardere primară uniformă. Puternic afectată de aciditatea solului. Bază dreaptă. Nr. inv. pr. TGH 176. PI. 8/7

8. Farfurie nedeterminabilă ca tip (fragment din bază cu corp); $d b=6 \mathrm{~cm} ; \mathrm{hp}=1,6$ cm. Pastă RM 5. Ardere primară uniformă. Uşor afectată de aciditatea solului. Bază inelară, cu un mic umbo în centru. Nr. inv. pr. TGH 177. Pl. $8 / 8$

9. Opait nedeterminabil ca tip (fragmentar, se păstrează două fragmente din cioc şi cinci din rezervor, cu dimensiuni cuprinse între $1,2-4,5 \mathrm{~cm}$ ). Pastă RM 5. Ardere primară uniformă. Puternic ars secundar pe interior şi partea inferioară a ciocului. Nr. inv. pr. TGH 178. Pl. 8/9

10. Vas nedeterminabil ca formă (patru fragmente din corp, cu dimensiuni cuprinse între 2,9-7 cm); gr.pr. = 1,6 cm. Pastă RM 10. Ardere primară incompletă. Uşor afectată de aciditatea solului. Nr. inv. pr. TGH 179.

11. Monedă ${ }^{15}$ Antoninus Pius; as; AE $K$ $10,98 \mathrm{~g} ; 25,8 \times 27,6 \mathrm{~mm}$. Av: IMP CAES T AEL HADR [ANTONINV]S AVG PIVS PP; cap laureat spre dreapta. Rv: TR POT XIIII COS IIII / S - C // [AN]NONA AVG în exergă; Annona şezând spre stânga, ţinând spice şi cornul abundenţei; în stânga, modius. RIC, p. 136, nr. 880, Roma, anii 150-151; BMC, p. 311 , nr. 1875, Roma, anii 150-151. Nr. inv. pr. TGH 180.

12. Piron (fragmentar); $L p=3,4 \mathrm{~cm}$. Fier oxidat, corodat. Cap rupt. Corp parţial păstrat, puternic afectat de coroziune, cu secţiune pătrată: $0,6 \mathrm{~cm}$. Vârf rupt. $\mathrm{Nr}$. inv. pr. TGH $18 \mathrm{I}$. PI. 8/12

\footnotetext{
15 Determinarea monedei şi descrierea au fost realizate de către Mihai Dima de la Muzeul Băncii Naţionale căruia îi mulųumim și pe această cale.
} 


\section{MORMÂNT NR. 31 (PI. 9)}

ardere pe loc

Localizare: secţiunea S 003, caroul 6.

Groapă de formă rectangulară, cu pereţii uşor evazał̧i, secţiune trapezoidală, fundul plat. $\mathrm{L}$ $=1,86 \mathrm{~m}, \mathrm{l}=1,04 \mathrm{~m}$, ad. $=0,74 \mathrm{~m}$; orientare VNV-ESE. Groapa, arsă (arsură discontinuă de $0,03 \mathrm{~m}$ ) este săpată în partea superioară în păınânt, iar partea inferioară în stâncă. Zona limitrofă prezintă urme de ardere.

Fragmentele de oase calcinate sunt dispuse în partea inferioară a gropii, compact, fără nici o operaţiune de separare a acestora de resturile rugului (depunere uniformă de cărbune de lemn, fragmente de bârne carbonizate în amestec cu fragmente de oase calcinate; grosimea acestui strat este de $0,20-0,30 \mathrm{~m}$ ). Groapa sepulcrală este puternic afectată de o intervenţie antropică (G3).

Inventar funerar: ceramică: trei urcioare, patru turibula, două opaiţe, un vas nedeterminabil ca formă; fier: un element de îmbinare, două piroane, o ţintă.

1. Urcior de tip U 43 (întreg); $d \mathrm{dg}=4,1$ $\mathrm{cm} ; \mathrm{d} \max =11,8 \mathrm{~cm} ; \mathrm{db}=6 \mathrm{~cm} ; \mathrm{h}=14 \mathrm{~cm}$. Pastă RM 3. Ardere primară uniformă. Uşor afectat de aciditatea solului. Nr. inv. pr. TGH 182. PI. $10 / 1$

2. Urcior, probabil de tip $\mathbf{U} 43$ (întregit); $\mathrm{dg}=4,2 \mathrm{~cm} ; \mathrm{dmax}=12,4 \mathrm{~cm} ; \mathrm{db}=5,7 \mathrm{~cm} ; \mathrm{h}=$ $14,5 \mathrm{~cm}$. Pastă RM 8. Ardere primară uniformă. Afectată de aciditatea solului. Nr. inv. pr. TGH 183. PI. $10 / 2$

\section{Urcior nedeterminabil ca tip} (fragmentar, se păstrează două fragmente din corp, cu dimensiuni cuprinse între $6-7 \mathrm{~cm}$ ). Pastă RM 8. Ardere primară uniformă. Uşor afectată de aciditatea solului. Urmă de toartă deasupra diametrului maxim. Nr. inv. pr. TGH 184.

\section{Turibulum nedeterminabil ca tip} (fragmentar, se pãstrează un fragment din buză, 18 fragmente din cupă şi un fragment picior cu cupă); dg = $22 \mathrm{~cm} ;$ hp $=14,5 \mathrm{~cm}$. Pastă RM 6 . Ardere primară uniformă. Urme de ardere secundară pe interiorul piciorului. Urme de materie organică la exterior. Buză înclinată spre exterior decorată cu alveole mici, realizate prin presarea cu degetele a marginii inferioare când pasta era crudă şi cu rotiţa dinţată pe marginea superioară. Corp în formă de cupă, cu două profilaturi pronunţate, marcate prin incizii realizate cu rotiţa dinţată. Picior înalt, gol pe interior. Nr. inv. pr. TGH 185. Pl. 10/4

5. Turibulum nedeterminabil ca tip (fragmentar, se păstrează două fragmente din buză cu corp); $d g=19 \mathrm{~cm} ; \mathrm{hp}=11,8 \mathrm{~cm}$. Pastă RM 6. Ardere primară uniformă. Slabe urme de ardere secundară. Urme de coroziune pe buză provenite în urma intrării în contact a piesei cu un obiect din fier. Buză înclinată spre exterior. arcuită, decorată cu alveole mici, realizate prin presarea cu degetele a marginii inferioare când pasta era crudă şi cu rotiţa dinţată pe marginea inferioară. Corp în formă de cupă, cu două profilaturi pronunţate, marcate prin incizii realizate cu rotiţa dinţată. Picior parţial păstrat, gol pe interior. Nr. inv. pr. TGH 186. PI. 11/5

6. Turibulum nedeterminabil ca tip (fragment din buză cu corp); $d g=17 \mathrm{~cm}$; hp = $12,5 \mathrm{~cm}$. Pastă RM 19. Ardere primară uniformă. Slabe urme de ardere secundară, la interior provenite, probabil, în urma utilizării. Buză înclinată spre exterior, decorată cu alveole mici, realizate prin presarea cu degetele a marginii inferioare când pasta era crudă şi cu rotiţa dinţată pe marginea superioară. Corp în formă de cupă, cu două profilaturi pronuntate, marcate prin incizii realizate $\mathrm{cu}$ rotiţa dinţată. Picior parţial păstrat, îngust, gol pe interior. Nr. inv. pr. TGH 187. PI. 11/6

7. Turibulum nedeterminabil ca tip (fragmentar, se păstrează un fragment din buză și două fragmente din corp cu dimensiuni cuprinse între 2,3-6,4 cm). Pastă RM 10. Ardere primară uniformă. Slabe urme de ardere secundară. Uşor afectată de aciditatea solului. Buză uşor înclinată spre exterior, decorată cu rotiţa dinţată pe marginea superioară. Nr. inv. pr. TGH 188. Pl. $11 / 7$

8. Opait Loeschcke X (întreg); L =8,3 cm; $1=5,5 \mathrm{~cm} ; \mathrm{h}=3,5 \mathrm{~cm}$. Pastă RM 8. Ardere primară uniformă. Slabe urme de ardere secundară pe bordură şi partea inferioară a ciocului. Uşor afectată de aciditatea solului. Disc neted, rotund, cu un orificiu de alimentare în 
centru. delimitat de bordură printr-un cordon, care se indreaptă spre cioc şi formează un canal, prevăzut cu un mic orificiu de ventilaţie. Bordura, prevăzută cu trei butoni dispuşi aproximativ simetric, este decorată cu semiove. Cioc alungit, cu un arzător, în formă de vârf de săgeată arondat. Rezervor tronconic. Baza concavă, delimitată prin două cercuri concentrice incizate are înscrisă în centru ştampila FORTIS. Nr. inv. pr. TGH 189. PI. 11/8

9. Opait Loeschcke X (fragmentar, se păstrează două fragmente din capac, altul din rezervor cu bază. unu din rezervor, două din cioc, cu dimensiuni cuprinse între $3-4,5 \mathrm{~cm}$ ). Pastă RM 9. Ardere primară uniformă. Uşor afectată de aciditatea solului. Disc neted, rotund. cu un orificiu de alimentare în centru, delimitat de bordură printr-un cordon proeminenet, care se îndreaptă spre cioc şi formează un canal, prevăzut cu un mic orificiu de ventilaţie. Bordura păstrează doi butoni. Rezervor tronconic. Bază concavă, delimitată prin două cercuri concentrice incizatc. $\mathrm{Nr}$, inv. pr. TGH 190. PI. $11 / 9$

10. Vas nedeterminabil ca formă (liagement din toartă cu dimensiuni de 5,3 × 2,4 cm). Pastá RM 8. Ardere primarã uniformă. Toartă lată, canelată. Nr. inv. pr. TGH 191.

11. Element de îmbinare (fragmentar); L $=3.9 \mathrm{~cm}$. Bronz (aliaj de cupru) auriu-verzui. Capătul părţii de îmbinare circular, parțial păstrat. Bară. cu secţiune patrulateră: $0,3 \times 0,2 \mathrm{~cm}$, îndoită la unul din capete. Nr. inv. pr. TGH 192. Pl. 11/11

12. Piron (fragmentar); $\mathrm{Lp}=2,6 \mathrm{~cm}$. Fier oxidat, corodat. Cap rupt. Corp parţial păstrat, cu secțiune pătrată: $0,8 \mathrm{~cm}$. Vârf rupt. Nr. inv. pr. TGII 193. Pl. 11/12

13. Piron (fragmentar); $\mathrm{Lp}=2,3 \mathrm{~m}$. Fier oxidat, corodat. Cap rupt. Corp parțial păstrat, puternic afectat de coroziune. Vârf rupt. Nr. inv. pr. TGH 194. Pl. $11 / 13$

14. Tintā (fragmentară); $L p=1,9 \mathrm{~cm}$. Fier oxidat, corodat. Cap rotund (?), parţial păstrat. Corp puternic afectat de coroziune, cu secţiune pătrată: $0,4 \mathrm{~cm}$. Vârf rupt. Nr. inv. pr. TGH 195. Pl. $11 / 14$

\section{MORMÂNT NR. 32 (Pl. 12)}

ardere pe loc

Localizare: secţiunea S 003, caroul 5.

Groapă de formă rectangulară, cu pereții uşor evazaţi, secţiune trapezoidală, fundul plat. $L$ $=1,97 \mathrm{~m} ; \mathrm{I}=0,82 \mathrm{~m}$; ad. $=0,58 \mathrm{~m}$; orientare: VNV-ESE. Groapa, arsă (arsură discontinuă de $0,03 \mathrm{~m}$ ) este săpată în stâncă.

Pentru amenajarea mormântului a fost demontată o parte din Z4.

Fragmentele de oase calcinate sunt dispuse în partea inferioară a gropii, compact, fără nici o operaţiune de separare a acestora de resturile rugului (depunere uniformă de cărbune de lemn, fragmente de bârne carbonizate în amestec cu fragmente de oase calcinate; grosimea acestui strat este de $0,04-0,14 \mathrm{~m}$ ). Groapa sepulcrală este puternic afectată de o intervenţie antropică (G4).

\section{Fără inventar.}

Intervenţii asupra monumentului ( $\mathrm{Pl} .2$ )

Asupra monumentului au avut loc patru intervenţii antropice, care afecteazà gropile sepulcrale. Toate interventiile antropice au fost făcute în acelaşi moment ${ }^{16}$.

G1 - groapă de intervenţie de formà aproximativ ovoidală în plan şi conică în secţiunea transversală.

Localizare: secţiunea S 002, caroul 5.

Dimensiuni: diametrul maxim la partea superioară $1,68 \mathrm{~m}$; adâncimea la care a apărut $0,14 \mathrm{~m}$; adâncimea maximă $0,46 \mathrm{~m}$.

Din punct de vedere stratigrafic sedimentul de umplutură al gropii este de culoare cenuşiu-negricioasă, conţine pietre de dimensiuni medii, fragmente de pământ ars de culoare roşie. În partea superioara a gropii a fost descoperit un fragment de capac în două ape (chaperon).

G2 - groapă de intervenţie de formă aproximativ ovoidală în plan şi conică în secţiunea transversală.

Localizare: secţiunea S 002, caroul 6.

${ }^{16}$ Gropile de intervenţic sunt practicate de la acelaşi nivel. 
Dimensiuni: diametrul maxim la partea superioară $1,48 \mathrm{~m}$; adâncimea la care a apărut $0,14 \mathrm{~m}$; adâncimea maximă $0,56 \mathrm{~m}$.

Din punct de vedere stratigrafic sedimentul de umplutură al gropii este de culoare cenuşiu-negricioasă, conţine pietre de dimensiuni medii, fragmente de pământ ars de culoare roşie.

G3 - groapă de intervenţie de formă aproximativ circulară în plan şi conică în secţiunea transversală

Localizare: secţiunea S 003, caroul 6.

Dimensiuni: diametrul maxim la partea superioară $1,48 \mathrm{~m}$; adâncimea la care a apărut $0,14 \mathrm{~m}$; adâncimea maximă $0,54 \mathrm{~m}$.

Din punct de vedere stratigrafic sedimentul de umplutură al gropii este de culoare cenuşiul-negricioasă, conţine pietre de dimensiuni medii, fragmente de pământ ars de culoare roşie.

G4 - groapă de intervenţie de formă circulară în plan şi conică în secţiunea transversală

Localizare: secţiunea S 003, caroul 5.

Dimensiuni: diametrul maxim la partea superioară $1,16 \mathrm{~m}$; adâncimea la care a apărut $0,14 \mathrm{~m}$; adâncimea maximă $0,58 \mathrm{~m}$.

Din punct de vedere stratigrafic sedimentul de umplutură al gropii este de culoare cenuşiu-negricioasă, conţine pietre de dimensiuni medii, fragmente de pământ ars de culoare roşie.

Datorită intervenţiilor ulterioare suferite, dea lungul timpului, de ansamblul funerar, nu a fost posibilă o analiză în detaliu a poziţionării şi distribuţiei spaţiale a inventarului funerar în cele patru morminte analizate mai sus.

De asemenea, trebuie menţionate 54 de obiecte descoperite in interiorul incintei funerare, ce nu pot fi atribuite, cu certitudine, niciunui mormânt din cele patru analizate în cadrul acestui studiu. Pentru acestea este foarte greu de realizat şi $O$ anumită legătură cu desfăşurarea unor ritualuri diverse efectuate post-înmormântare.

\section{Catalogul obicctelor descoperite în interiorul incintei funerare:}

1. Urcior, probabil de tip U 9 (fragmentar, se păstrează gura cu gât şi o parte din corp, trei fragmente din corp şi un fragment din toartă); $d g=6,3 \mathrm{~cm} ; \mathrm{hp}=7,4 \mathrm{~cm}$. Pastă RM 16. Ardere primară incompletă. Urme de ardere secundară pe corp. Uşor afectată de aciditatea solului. Nr. inv. pr. TGH 734. PI. 13/1

2. Urcior, probabil de tip U 25 (fragmentar, se păstrează fragmente din buză, gât, corp, bază, toartă); $d g=4,2 \mathrm{~cm} ; \mathrm{db}=4,6$ $\mathrm{cm}$; hestimativ $=22,5 \mathrm{~cm}$. Pastă RM 3 . Ardere primară uniformă. Urme de ardere secundară pe bază. Uşor afectată de aciditatea solului. Nr. inv. pr. TGH 735. PI. 13/2

\section{Urcior nedeterminabil ca tip} (fragmentar, se păstrează două fragmente din partea superioară a corpului); dmax $=9,4 \mathrm{~cm}$; hp $=5 \mathrm{~cm}$. Pastă RM 5. Ardere primară uniformă. Puternic afectată de aciditatea solului. Corp globular. Nr. inv. pr. TGH 736. PI. 13/3

4. Urcior nedeterminabil ca tip (fragmentar, se păstrează două fragmente din bază şi opt fragmente din corp); db = 5,9 cm; hp $=4,6 \mathrm{~cm}$. Pastă RM 3. Ardere primară uniformă. Afectată de aciditatea solului. Bază inelară, cu un mic umbo în centru. Nr. inv. pr. TGH 737. Pl. $13 / 4$

5. Urcior nedeterminabil ca tip (fragmentar, se păstrează nouă fragmente din corp şi două din bază); db = 4 cm. Pastă RM 3 . Ardere primară uniformă. Puternic afectată de aciditatea solului. Bază inelară. Nr. inv. pr. TGH 738. Pl. $13 / 5$

6. Oală, probabil de tip $O 7$ (întregibilă, se păstrează un fragment din buză cu corp, patru fragmente din corp şi un fragment din bază cu corp); $\mathrm{dg}=14,3 \mathrm{~cm} ; \mathrm{db}=9,2 \mathrm{~cm}$; hestimativ = 19,2 cm. Pastă RM 7. Ardere primară uniformă. Puternic arsă secundar pe interior. Afectată de aciditatea solului. Nr. inv. pr. TGH 739. Pl. 13/6

7. Oală, probabil de tip $\mathbf{O} 2$ (întregibilă, se păstrează trei fragmente din buză cu corp, 12 fragmente din corp, un fragment din bază); dg = $14 \mathrm{~cm} ; \mathrm{db}=7,9 \mathrm{~cm}$; hestimativ $=17 \mathrm{~cm}$. Pastă RM 16. Ardere primară uniformă. Uşor afectată 
de aciditatea solului. Nr. inv. pr. TGH 740. PI. $14 / 7$

8. Oală, probabil de tip $O 2$ (întregibilă, se păstrează un fragment din buză cu corp, un fragment corp şi un fragment bază cu corp); $\mathrm{dg}=$ $13 \mathrm{~cm} ; \mathrm{db}=9 \mathrm{~cm}$; hestimativ $=17,2 \mathrm{~cm}$. Pastă RM 6. Ardere primară uniformă. Ardere sccundară. Urme de substanţă organică pe interiorul buzei. Nr. inv. pr. TGH 741. Pl. 14/8

9. Oală, probabil de tip $O 7$ (întregibilă, se păstrează patru fragmente din buză cu corp, 16 fragmente din corp și două fragmente din bază $\mathrm{cu}$ corp); $\mathrm{dg}=13 \mathrm{~cm} ; \mathrm{db}=7,4 \mathrm{~cm}$; hestimativ $=18,4 \mathrm{~cm}$. Pastă RM 6. Ardere primară incompletă. Ardere secundară la interior. Uşor afectată de aciditatea solului. $\mathrm{Nr}$. inv. pr. TGII 743. PI. 14/9

10. Oală, probabil de tip $\mathrm{O} 2$ (fragmentară, se păstrează un fragment din buză cu corp şi 25 de fragmente din corp); $d g=13 \mathrm{~cm} ; \mathrm{hp}=7,5 \mathrm{~cm}$. Pastă RM 21. Ardere primară incompletă. Nr. inv. pr. TGH 742. Pl. 15/10

11. Oală, probabil de tip $O 7$ (fragmentară, se păstrează un fragment din buză cu corp şi cinci (ragmente din corp): $d g=11 \mathrm{~cm} ; \mathrm{hp}=4 \mathrm{~cm}$. Pastă RM 6. Ardere primară incompletă. Uşor afectată de aciditatea solului. Nr. inv. pr. TGH 744. PI. 14/11

12. Oală, probabil de tip $O \quad 2$ (fragmentară, se păstrează un fragment din buză cu corp); $d g=17,8 \mathrm{~cm} ; \mathrm{hp}=2,7 \mathrm{~cm}$. Pastă RM 1. Ardere primară uniformă. Afectată de aciditatea solului. Nr. inv. pr. TGH 745. PI. $15 / 12$

13. Oală, probabil de tip $O \quad 8$ (fragmentară, se păstrează un fragment din buză cu corp); $d g=14,2 \mathrm{~cm} ; \mathrm{hp}=2,5 \mathrm{~cm}$. Pastă RM 1. Ardere primară uniformă. Puternic afectată de aciditatea solului. Nr. inv. pr. TGH 746. Pl. $15 / 13$

14. Oală nedeterminabilă ca tip (fragmentară, se păstrează patru fragmente din bază cu corp); db=12,8 cm; hp = $3 \mathrm{~cm}$. Pastă RM 10. Ardere primară incompletă. Urme de ardere secundară pe bază, provenite, probabil, în urma utilizării. Bază dreaptă. Nr. inv. pr. TGH 747. PI. 15/14
15. Oală nedeterminabilă ca tip (fragmentară, se păstrează două fragmente din buză, unul din toartă şi 26 de fragmente din corp); $\mathrm{dg}=12,2 \mathrm{~cm}$. Pastă RM 16. Ardere primară uniformă. Slabe urme de ardere secundară. Puternic afectată de aciditatea solului. Buză înclinată spre exterior, rotunjită, îngroşată. Este prevăzută cu o toartă canelată, ataşată sub buză. Nr. inv. pr. TGH 748. Pl. 15/15

16. Cupă de tip C 16.2, imitaţie de vas cu pereţi fini (întregită); $d g=5,6 \mathrm{~cm} ; \mathrm{db}=3,4 \mathrm{~cm}$; $\mathrm{h}=8,2 \mathrm{~cm}$; gr.pr. $=3 \mathrm{~mm}$. Pastă RM 5. Ardere primară uniformă. Uşor afectată de aciditatea solului. Particularitate: trecerea de la corp spre bază este marcată printr-o profilatură externă, pronunţată. Nr. inv. pr. TGH 749. PI. 15/16

17. Cupă nedeterminabilă ca tip, imitaţie de vas cu pereţi fini (fragmentară, se păstrează un fragıment din bază cu corp); db=4,2 cm; hp = $1,8 \mathrm{~cm}$. Pastă RM 3. Ardere primară incompletă. Puternic afectată de aciditatea solului. Nr. inv. pr. TGH 750. Pl. 15/17

18. Cupă nedeterminabilă ca tip, imitaţie de vas cu pereţi fini (fragmentară, se păstrează un fragment din bază cu corp); db $=4 \mathrm{~cm}$; hp = $1,7 \mathrm{~cm}$; gr.pr. $=3 \mathrm{~mm}$. Pastă RM 5. Ardere primară uniformă. Uşor afectată de aciditatea solului. Bază inelară. Nr. inv. pr. TGH 751. Pl. $15 / 18$

19. Cupă nedeterminabilă ca tip, imitaţie de vas cu pereţi fini (fragmentară, se păstrează două fragmente din bază cu corp); db $=4 \mathrm{~cm} ; \mathrm{hp}$ $=1,7 \mathrm{~cm}$; gr.pr. $=4 \mathrm{~mm}$. Pastă RM 3. Ardere primară uniformă. Afectată de aciditatea solului. Bază inelară. Nr. inv. pr. TGH 752. Pl. 15/19

20. Cupă nedeterminabilă ca tip, imitaţie de vas cu pereţi fini (fragmentară, se păstrează două fragmente din bază cu corp); db $=4 \mathrm{~cm}$; hp $=1,5 \mathrm{~cm}$; gr.pr. $=4 \mathrm{~mm}$. Pastă RM 12. Ardere primară uniformă. Puternic afectată de aciditatea solului. Bază inelară. Nr. inv. pr. TGH 753. PI. $15 / 20$

21. Cupă nedeterminabilă ca tip, imitaţie de vas cu pereţi fini (fragmentară, se păstrează un fragment din bază cu corp şi două fragmente din corp); $\mathrm{db}=3,2 \mathrm{~cm} ; \mathrm{hp}=1,9 \mathrm{~cm} ;$ gr.pr. $=3$ mm. Pastă RM 8. Ardere primară uniformă. 
Puternic afectată de aciditatea solului. Bază inelară. Nr. inv. pr. TGH 754. Pl. 15/21

22. Cupă nedeterminabilă ca tip, imitaţie de vas cu pereţi fini (fragmentară, se păstrează un Iragment din bază cu corp şi trei fragınente din corp); $\mathrm{db}=2,8 \mathrm{~cm} ; \mathrm{hp}=2 \mathrm{~cm} ;$ gr.pr. $=3$ mm. Pastă RM 5. Ardere primară uniforınă. Puternic afectată de aciditatea solului. Bază inelară. Nr. inv. pr. TGH 755. PI. 15/22

23. Cupă/Bol nedeterminabil ca tip, imitaţie de vas cu pereţi fini (fragment din corp cu dimensiuni de $4 \times 1,3 \mathrm{~cm}$ ); gr.pr. $=2 \mathrm{~mm}$. Pastă RM 3. Ardere primară uniformă. Puternic alectată de aciditatea solului. Nr. inv. pr. TGH 756.

24 Cupă/Bol, probabil de tip CB 1 (fragment din buză cu corp); dg = $10 \mathrm{~cm} ; \mathrm{hp}=$ $3,1 \mathrm{~cm}$. Pastă RM 8. Ardere primară uniforınă. Uşor afectată de aciditatea solului. Nr. inv. pr. TGIH 757. Pl. 15/24

25. Cupă/Bol nedeterminabil ca tip (fragmentar, se păstrează un fragment din buză şi şase fragmente din corp); $d g=10 \mathrm{~cm}$. Pastă RM 8. Ardere primară incompletă. Buză uşor inclinată spre interior. Buza este delimitată de corp prin două caneluri. Corp decorat cu rotita dinţată. Nr. inv. pr. TGH 758. PI. 15/25

26. Cupă/Bol, probabil de tip CB 1 (fragment din buză cu corp); dg = $13 \mathrm{~cm} ; \mathrm{hp}=$ $2,2 \mathrm{~cm}$. Pastă RM 5. Ardere primară uniformă. $\Lambda$ fectată de aciditatea solului. Nr. inv. pr. TGH 759. PI. 15/26

\section{Capac nedeterminabil ca tip} (fragmentar, se păstrează butonul cu pereţii); dbuton $=2,7 \mathrm{~cm} ;$ hp $=2 \mathrm{~cm}$. Pastă RM 21 . Ardere primară incompletă. Buton scurt, uşor prolilat. Nr. inv. pr. TGH 760. PI. 15/27

28. Opait Loeschcke $X$ (fragment din bază cu rezervor); $L p=4,1 \mathrm{~cm} ; \mathrm{lp}=3 \mathrm{~cm}$. Pastă RM 9. Ardere primară uniformă. Urme de substanţe organice. Rezervor tronconic. Baza, delimitată prin două cercuri concentrice are înscrisă în centru ştampila CA[SSI]. Nr. inv. pr. TGH 761. PI. 15/28

29. Opait Loeschcke $X$ (fragment din capac); $L p=2,8 \mathrm{~cm} ; \mathrm{lp}=4,9 \mathrm{~cm}$. Pastă RM 9. Ardere primară uniformă. Puternic ars secundar. Puternic afectată de aciditatea solului. Disc neted, delimitat de bordură printr-un cordon, care se îndreaptă spre cioc şi formează un canal, prevăzut cu un mic orificiu de ventilaţie. Bordură lată. Nr. inv. pr. TGH 762. PI. 15/29

30. Opait Loeschcke $X$ (fragmentar, se păstrează un fragment din capac, un fragment din partea inferioară a ciocului și un fragment din bază, cu dimensiuni cuprinse între 1,7-3,7 cm). Pastă RM 14. Ardere primară uniformă. Puternic afectată de aciditatea solului. Disc neted, rotund, cu un orificiu de alimentare, delimitat de bordură printr-un cordon proeminent. Bordura păstrează un buton. Bază concavă, delimitată prin trei cercuri concentrice incizate. Nr. inv. pr. TGH 763. Pl. 15/30

31. Opaiţ Loeschcke $X$ (fragmentar, se păstrează cinci fragmente din capac şi şapte din rezervor, cu dimensiuni cuprinse între $1-3 \mathrm{~cm}$ ). Pastă RM 3. Ardere primară uniformă. Slabe urme de ardere secundară. Puternic afectată de aciditatea solului. Disc delimitat de bordură printr-un cordon, care se îndreaptă spre cioc si formează un canal. Bordura păstrează un buton. Cioc cu un arzător. Nr. inv. pr. TGH 764. Pl. $16 / 31$

32. Opait nedeterminabil ca tip (fragmentar, se păstrează două fragmente din partea inferioară, cu dimensiuni de $3,6 \times 2,8$ cm). Pastă RM 14. Ardere primară uniformă. Puternic ars secundar. Puternic afectată de aciditatea solului. Rezervor tronconic (?) Bază concavă, delimitată prin trei cercuri concentrice incizate. Nr. inv. pr. TGH 765. PI. 16/32

33. Opait Loeschcke $X$ (fragmentar, se păstrează un fragment din canal şi două din partea inferioară a ciocului, cu dimensiuni cuprinse între 2,2-3,5 cm). Pastă RM 9. Ardere primară uniformă. Urme de ardere secundară. Nr. inv. pr. TGH 766. PI. 16/33

34. Vas nedeterminabil ca formă (fragmentar, se păstrează 33 de fragmente din corp, neîntregibile, cu dimensiuni cuprinse între $1-9,4 \mathrm{~cm})$. Pastă RM 16. Ardere primară uniformă. Puternic afectată de aciditatea solului. Urme de materie organică. Nr. inv. pr. TGH 767.

35. Cuarţ (întreg); $L=2 \mathrm{~cm}$. Se păstrează un fragment de dimensiuni mici. Nr. inv. pr. TGH 768. Pl. 16/35 
36. Fibulă (fragmentară, lipseşte acul şi o parte din portagrafă); $L p=5,2 \mathrm{~cm}$. Bronz. Patină verde. Fibulă cu genunchi. Cap mic, semirotund. Resort format din şase spire. Portagrafã parţial păstrată, probabil dreptunghiulară. Corp curbat. Picior scurt. Nr. inv. pr. TGH 769. Pl. 16/36

37. Scoabă (fragmentară); $L p=0,5 \mathrm{~cm}$. Fier oxidat, corodat. Un cui rupt, celălalt păstrat în întregime: Lcui $=4,5 \mathrm{~cm}$. Bară ruptă. Nr. inv. pr. TGH 770. Pl. 16/37

38. Piron (fragmentar); $\mathrm{Lp}=20,4 \mathrm{~cm}$. Fier oxidat, corodat. Cap rupt. Corp afectat de coroziunc, indoit, cu secţiune patrulateră: $1,3 \times$ $0.6 \mathrm{~cm}$. Vârf rupt. Nr. inv. pr. TGH 771. Pl. $16 / 38$

39. Piron (fragmentar); $\mathrm{Lp}=8,3 \mathrm{~cm}$. Fier oxidat, corodat. Cap rupt. Corp afectat de coroziune, puternic îndoit, $\mathrm{cu}$ secţiune patrulateră: $0,5 \times 0,3 \mathrm{~cm}$. Vârf rupt. $\mathrm{Nr}$. inv. pr. TGH 772. Pl. 16/39

40. Piron (fragmentar); $\mathrm{Lp}=6,6 \mathrm{~cm}$. Fier oxidat, corodat. Cap rupt. Corp afectat de coroziune, cu secţiune circulară: $0,8 \mathrm{~cm}$. Vârf rupt. Nr. inv. pr. TGH 773. Pl. 16/40

41. Piron (fragmentar); $\mathrm{Lp}=6,4 \mathrm{~cm}$. Fier oxidat, corodat. Cap rupt. Corp parţial păstrat, cu secţiune circulară: $1,1 \mathrm{~cm}$. Vârf rupt. Nr. inv. pr. TGH 774. Pl. 16/4 I

42. Piron (fragmentar); $\mathrm{Lp}=4,1 \mathrm{~cm}$. Fier oxidat, corodat. Cap rupt. Corp parţial păstrat, afectat de coroziune, cu secţiune patrulateră: 0,5 $\times 0,3 \mathrm{~cm}$. Vârf rupt. Nr. inv. pr. TGH 775. Pl. $16 / 42$

43. Piron (fragmentar); $L p=3,8 \mathrm{~cm}$. Fier oxidat, corodat. Cap rupt. Corp parţial păstrat, puternic afectat de coroziune, cu secţiune circulară: $0,6 \mathrm{~cm}$. Vârf rupt. Nr. inv. pr. TGH 776. Pl. $16 / 43$

44. Piron (fragmentar); $\mathrm{Lp}=3,5 \mathrm{~cm}$. Fier oxidat, corodat. Cap rupt. Corp parţial păstrat, putcrnic afectat de coroziune, cu secţiune patrulateră: $0,5 \times 0,4 \mathrm{~cm}$. Vârf rupt. Nr. inv. pr. TGI.I 777. Pl. 16/44

45. Piron (fragmentar); $\mathrm{Lp}=3,2 \mathrm{~cm}$. Fier oxidat, corodat. Cap rotund (?), parțial păstrat. Corp parţial păstrat, cu secţiune patrulateră: 0,5 $\times 0.4 \mathrm{~cm}$. Vârf rupt. Nr. inv. pr. TGH 778 . PI. $16 / 45$
46. Piron (fragmentar); $\mathrm{Lp}=3,2 \mathrm{~cm}$. Fier oxidat, corodat. Cap rupt. Corp parţial păstrat, puternic afectat de coroziune, cu seç̧iune patrulateră: $0,6 \times 0,4 \mathrm{~cm}$. Vârf rupt. $\mathrm{Nr}$. inv. pr. TGH 779. Pl 16/46

47. Piron (fragmentar); $\mathrm{Lp}=2,9 \mathrm{~cm}$. Fier oxidat, corodat. Cap rupt. Corp parţial păstrat, cu secţiune pătrată: $0,4 \mathrm{~cm}$. Vârf rupt. $\mathrm{Nr}$. inv. pr. TGH 780. PI. 16/47

48. Piron (fragmentar); $\mathrm{Lp}=2,8 \mathrm{~cm}$. Fier oxidat, corodat. Cap rotund, aplatizat. Corp parţial păstrat, cu secţiune pătrată: $0,6 \mathrm{~cm}$. Vârf rupt. Nr. inv. pr. TGH 781. Pl. 16/48

49. Piron (fragmentar); $\mathrm{Lp}=2,7 \mathrm{~cm}$. Fier oxidat, corodat. Cap rupt. Corp parţial păstrat, puternic afectat de coroziune, cu secţiune circulară: $1 \mathrm{~cm}$. Vârf rupt. Nr. inv. pr. TGH 782 . PI. 16/49

50. Piron (fragmentar); $\mathrm{Lp}=2,5 \mathrm{~cm}$. Fier oxidat, corodat. Cap rupt. Corp parţial păstrat, cu seç̧iune patrulateră: $0,4 \times 0,3 \mathrm{~cm}$. Vârf tocit. $\mathrm{Nr}$. inv. pr. TGH 783. Pl. 16/50

51. Piron (fragmentar); $L p=2,5 \mathrm{~cm}$. Fier oxidat, corodat. Cap rupt. Corp parţial păstrat, cu secţiune patrulateră: $0,6 \times 0,5 \mathrm{~cm}$. Vârf rupt. Nr. inv. pr. TGH 784. PI. 16/51

52. Tintă (fragmentară); $L p=2,2 \mathrm{~cm}$. Fier oxidat, corodat. Cap rupt. Corp puternic afectat de coroziune, cu secţiune patrulateră: $0,3 \times 0,2$ $\mathrm{cm}$. Vârf tocit. Nr. inv. pr. TGH 785. PI. 16/52

53. Obiect neidentificat (fragmentar); $2,4 \times$ $2,1 \mathrm{~cm}$. Fier oxidat, corodat. Se păstrează un fragment: $\mathrm{gr}=0,2-0,5 \mathrm{~cm}$. Nr. inv. pr. TGH 786 . Pl. 16/53

54. Obiect neidentificat (fragmentar); $2 \times$ $1,7 \mathrm{~cm}$. Fier oxidat, corodat. Se păstrează un fragment subţire: $\mathrm{gr}=0,2 \mathrm{~cm}$, prevăzut cu un nit în centru. Nr. inv. pr. TGH 787. Pl. 16/54

\section{Concluzii}

Incinta funerară, care face obiectul studiului nostru, are două faze de funcţionare, patru înmormântări (M 29, M 30, M 31 şi M 32) şi patru perturbări antropice ulterioare înmormântărilor (G 1, G 2, G 3 şi G 4).

Pentru construirea incintei în faza I de funcţionare a fost necesară realizarea unei terase în stâncă pentru a conferi planeitate incintei. 
Primei faze de funcţionare a incintei funerare, descrise de zidurile $\mathbf{Z 1 a}, \mathbf{Z 2 a}, \mathbf{Z 3}$ şi $\mathbf{Z 4}$ îi corespunde mormântul cu sigla $\mathrm{M} 31$, acesta reprezentând, de altfel, prima înmormântare. Celei de-a doua faze de funcţionare, încadrată de zidurile Z1, Z2, Z5 şi $\mathbf{Z 6}$ îi corespund mormintele M 29, M 30 si $M$ 32. Plasarea mormintelor M 30 şi M 32 într-o altă etapă, în raport cu $M 31$ este demonstrată de următoarele argumente: din punct de vedere stratigrafic, latura de VNV a mormântului M 30 suprapune zidul $\mathbf{Z 3}$ (pietrele din acestea au urme de ardere), iar pentru amenajarea mormântului M 32 a fost demontată o mare parte din zidul $\mathbf{Z 4}$, în zona gropii sepulcrale fiind observată doar amprenta zidului. În absenta altor detalii stratigrafice, între mormintele din faza a doua de funcţionare a incintei funerare nu se pot stabili repere cronologice care să le situeze pe paliere diferite.

Din punct de vedere cronologic zidurile corespunzătoare fazei a doua de funcţionare sunt construite într-un moment ulterior în raport $\mathrm{cu}$ cele trei morminte din faza a doua (M 29, M 30, $M$ 32). Acest rap̧ionament este demonstrat de faptul că zidurile din apropierea celor trei complexe nu prezintă urme de ardere, iar mormântul M 30 este construit anterior zidului Z5, partea superioară a gropii mormântului fiind suprapusă de acesta.

$\mathrm{Nu}$ este exclusă o posibilă structură tumulară a incintei, argumentaţie ce nu poate fi susţinută datorită stării precare de conservare a ansamblului funerar. În acest context se impune menfionarea câtorva elemente de arhitectură funerară, descoperite în poziție secundară, în imediala apropiere, piese ce pot fi atribuite acestei incinte funerare (doi lei funerari, o cornişă, un medalion funerar fragmentar şi un con de pin funerar).

Incinta funerară analizată are cele mai apropiate analogii, ca modalitate de construcţie, la Alburnus Maior. în urma cercetărilor arheologice din cadrul Programului Naţional de Cercetare Alburnus Maior au fost identificate alte opt asemenea incinte funerare rectangulare (patru în necropola de incineraţie de la Tăul
Secuilor-Pârâul Porcului ${ }^{17}$, una în zona funerară Carpeni $^{18}$; două în necropola de incineraţie din Tarina $^{19}$, una în necropola de incineraţie de la Tăul Găuri-Hop ${ }^{20}$ ). Toate incintele amintite sunt amenajări rectangulare din piatră legată cu pământ, patru dintre ele având, probabil, ultima asiză sub formă de chaperon. În interiorul acestora au fost identificate unul sau mai multe morminte de incineraţie.

Asemenea construcţii funerare au fost semnalate şi investigate în provincia Dacia Superior: la Cinciş ${ }^{21}$ (cu două compartimentări), în interiorul cărora au fost identificate patru morminte $^{22}$, la Ulpia Traiana Sarmizegetusa, în necropola de vest a fost cercetată o incintă rectangulara ${ }^{23}$. De asemenea, astfel de construcţii funerare au fost cercetate în cadrul necropolei de est a aceluiaşi sit $^{24}$.

Construcţii funerare asemănătoare au fost cercetate în mai multe provincii occidentale ale imperiului: Pannonia Inferior (Matrica ${ }^{25}$ ), Gallia Cisalpina Boretto $^{26}$, incintă funerară rectangulară ${ }^{27}$ ), Gallia Belgica (WadernOberlöstern $^{28}$, incintă funerară rectangulară ${ }^{29} \mathrm{cu}$ platformă pentru monument funerar, în interiorul

17 Crăciun. Moga 2003, $37-0$ incintă funerarã rectangulară cu laturile $7.80 \times 5.20 \mathrm{~m}$, ultima asiză este realizatā utilizând blocuri de piatră de forma unui chuperon. cercetată partial: Neagu. Bocan 2007-2008. 93-122.

${ }^{18}$ Rusu-Bolindeł et alii 2003, 389. 406. fig. 10 - o incintă funerară rectangulară, cercetatã parł̧ial, în interiorul căreia au fost descoperite douã morminte de incineratie ambele complexe dispun de câte o amenajare anterioară, sub forma unui ring de piatră.

${ }^{19}$ CCA 2005. 298 -o incintã funcrară rectangulară cu dimensiunile de $7,20 \times 6,85 \times 6,25 \times 5.60 \mathrm{~m}$. ultima asiză este realizatã utilizând blocuri de piatrã de forma unui chaperon, cu un mormânt de incinera|ie: CCA 2006. 298 o alıă incintă patrulaterả cu un mormânt de incinerație.

${ }^{20}$ Moga et alii 2003, 205, 226. lig. 12. 248. fig. $3-0$ incintă funerară, de formá patrulateră cu laturile aproximativ egale. cu latura de $5 \mathrm{~m}$, cu un mormânt de incineratie.

${ }^{21}$ Incintã funerară de lormă rectangulară. cu dimensiunile de 10,80 × $9.25 \mathrm{~m}$; vezi Floca. Valca 1965, 163-194.

${ }^{22}$ Trei morminte de incinerap̧ic şi unul cu ritul incert.

23 Allen 1993, 397-400; CCA 2003, 267-269. în curs de cercetare.

${ }^{24}$ Simion et alii 2004, 84, nota 162. Într-una dintre incinte au fost identificate patru morminte de incineraţie.

${ }^{25}$ Topal 2000. 199. fig. 20.2.

${ }^{26}$ Ortalli 1998. 63, fig. 11 (incinta lunerarā a Concordiilor)

${ }^{27} \mathrm{Cu}$ dimensiunile de $10.8 \times 9.2 \mathrm{~m}$.

${ }^{28}$ Abegg-Wigg 2000, $113,12.2$.

${ }^{29} \mathrm{Cu}$ dimensiunile de $6 \times 4,9 \mathrm{~m}$. 
căreia a fost identificat un mormânt de incineraţic), Gallia Celtica (Biberist-Spitalhof ${ }^{30}$, incintă funerară cu două faze ${ }^{31}$, în interiorul căruia au fost identificate un mormânt de tip bustum şi o urnă) etc.

În ceea ce priveşte modalitatea de înmormântare a defuncţilor, analogii se întâlnesc în toate provinciile romane, cu o frecvenţă mai ridicată în cele subsumate termenului generic de Illyricum: Dacia Superior (Alburnus Maior ${ }^{32}$, Boteş/Corabia $^{33}$, Apulum ${ }^{34}$, Muncelu-Brad ${ }^{35}$, Cinciş $^{36}$, Ulpia Traiana Sarmizegetusa ${ }^{37}$, Tibiscum ${ }^{38}$ ); Dacia Inferior (Romula ${ }^{39}$ ); Pannonia Inferior (Matrica ${ }^{40}$, Aquincum $^{\text {Hh }}$ ); Moesia Superior (Viminacium ${ }^{42}$, KosmajGuberavat) $^{43}$, Ulpiana ${ }^{44}$, Matka ${ }^{45}$, Mala Kopašnica $^{40}$, Naissus ${ }^{47}$, Skopje ${ }^{48}$, Velika Grabovnika $^{49}$, Boljetin ${ }^{50}$, Zuto Brdo ${ }^{51}$ ); Dalmatia (Docle $^{52}$, Stup ${ }^{53}$, Rogatica ${ }^{54}$, Komini ${ }^{55}$ ); Gallia Narbonesis (Lyon ${ }^{56}$, SaintPaul-Trois-Chateâux ${ }^{57}$ ); Gallia Celtica (BiberistSpitalhof $^{58}$ ); Britannia (Londinium ${ }^{59}$ ) etc.

\footnotetext{
${ }^{30}$ Schucany 2000, 118-124. fig. 13/3, 13/4.

"Cu dimensiunile de $9 \times 9 \mathrm{~m}$.

32 Necropola de incineratic de la Tăul Găuri-Hop (Moga et alii 2003. 193-251: CCA 2003. 104-105; necropola de incinerap̧ie de la Tăul Corna (Alburnus Maior III); necropola de incinerapic de la Jig-Piciorag CCA 2004, 262264: Tarina CCA 2004, 262-264; CCA 2005, 298-313; CCA 2006, 297-298.

Floca 1936-1940, 160-173.

${ }^{34}$ Protase 1974, 141-159.

35 Rusu 1979. 219.

36 Floca. Valca 1965, 171-192.

${ }^{37}$ Allen 1993, 398.

38 Petrovsky 1979. 205-210.

${ }^{39}$ Babes 1970, 177-180.

(1) Topal 2000. 199.

11 Topal 1993, 78-80.

$12 \%$ olović, Jordović 1990, 77-110.

4. Jovanović 1984, 100, lipul C4.

"Srejović 1965.71.

${ }^{45}$ Mikulčić 1975, 93.

46 Zolović 1968. 19.

17 \%olović 1968, 27.

${ }^{48}$ Mikulčić 1975. 89.

49 Zolović 1968, 24.

50 Jovanović 1984. 100.

"Kosorić. Totorović 1995, 271-272.

\$2 Garašanin 1968. 90.

5.3 Ćremonšnika 1930. 211-225.

5 Jovanović 1984. 101.

55 Jovanović 1984, 101-103.

56 Bel. Tranoy 1993, 97. 133 morminte de tip bustum

${ }^{57}$ Bel. Tranoy 1993. 96, 93 morminte de tip bustum.

${ }^{5 \mathrm{~K}}$ Scliucany 2000.120.
}

Inventarul celor patru morminte analizate mai sus este constituit din obiecte din ceramică (urcioare, turibula, oale, cupe, farfurii, opaiţe), şi obiecte din metal: bronz (monedă); fier (scoabă, element de îmbinare, piroane, ţinte).

Cea mai mare parte a obiectelor ceramice prezintă un grad mare de fragmentaritate, atât datorită caracteristicilor legate probabil de specificul ritului şi ritualului funerar din perioada romană (arderea pe rug a ofrandelor, depunerea în context funerar imediat după momentul cremaţiei), cât şi datorită caracteristicilor pedologice specifice zonei Roşia Montană (aciditatea ridicată contribuie la deteriorarea artefactelor). De asemenea, intervenţiile ulterioare asupra complexelor arheologice în discuţie au contribuit la starea de fragmentaritate a obiectelor.

Pe baza observaţiilor stratigrafice şi a analogiilor coroborate $\mathrm{cu}$ analiza inventarului funerar (două artefacte datate clar în secolul al II-lea p. Chr.: moneda M 30 emisă în timpul domniei lui Antonius Pius şi un opaiţ din M 31 cu ştampila FORTIS), ansamblul funerar se poate data pe parcursul secolului al II-lea p. Chr.

${ }^{59}$ Barber et alii 1990, 5-8, fig. 3-5. 


\section{BIBLIOGRAFIE}

Abegg-Wigg 2000 - A. Abegg-Wigg, A Roman Cemetery in the eastern Civitas Treverorum. Preliminary report on the excavations in Wadern-Oberlöstern in Northwestern Saarland (Germany), în Burial, Society and Context in the Roman World, Oxford, 2000, p. 112-117.

Alburnus Maior I - Alburnus Maior (coordonator P. Damian), vol. I, Bucureşti, 2003.

Alburnus Maior III - Necropola romană de incineraţie de la Tăul Corna, vol. III, partea I (coord. P. Damian), Cluj-Napoca, 2008.

Allen 1993 - T. Allen, Interim report on two seasons of excavations of burial enclosure in the east cemetery of Ulpia Traiana Sarmizegetusa, 1982-1984, ActaMusNapoca, 26-30, 1993, 1-2, p. 397-400.

Babeş 1970 - M. Babeş, Zu den Bestattunsgarten im nördlichen Flachgräberfeld von Romula. Ein Beitrag zur Grabtypologie des römischen Daziens, Dacia N.S., XIV, 1970, p. 167-207.

Barber et alii 1990 - B. Barber, D. Bowsher, K. Whittaker, Recent Excavations of a Cemetery of Londinium, Britannia, 21, 1990, p. 1-12.

Bel, Tranoy 1993 - V. Bel, L. Tranoy, Note sur le busta dans le sud-est de la Gaule, Römerzeitlische Gräber als Quellen zu Religion, Bevölkerungsstruktur und Sozialgeschichte. Internationale Fachkonferenz vom 18.-20. Februar 1991 im Institut für Vor- und Frühgeschichte der Johannes Gutenberg-Universitat Mainz, Mainz, 1993, p. $95-110$.

BMC - H. Mattingly, Coins of the Roman Empire in the British Museum, IV, Antoninus Pius to Commodus, Londra, 1940

Crăciun, Moga 2003 - C. Crăciun, V. Moga, Cercetări de teren şi sondaje, în Alburnus Maior I, 2003, p. 3342.

Čremonšnika 1930 - G. Čremonšnika, Nalazi iz rimskog doba na Stupu kod Sarajeva, GlasSarajevo, 42, 1930, p. 211-235.

Floca 1936-1940 - O. Floca, Cercetări arheologice in Munfii Zlatnei, pe Dealıl Boteș şi Corabia. Raport inaintat Comisiunii Monumentelor Istorice, sectia pentru Transilvania, Cluj, AISC, 3, 1936-1940, p. 30-173.

Floca, Valea 1965 - O. Floca, M. Valea, Villa rustica și necropola de la Cinciș, ActaMusNapoca. 2 1965, p. 163194.

Garašanin 1968 - M. Garašanin, Razmatraja o necropolama tipa Mala Kopašnica-Sasc', Godišnjak Sarajevo, VI, 1968, 4, p. 5-35.

Jovanović 1984 - Al. Jovanović, Rimske Necropole na teritoria Jugos/avije, Beograd, 1984.

Kosorić, Totorović 1995 - M. Kosorić, J. Totorović, , Grad" Nasele Julobrdske Kulturne Grune, Starinar, 1314, 1962-1963 (1965), p. 267-274.

Mikulčić 1975 - I. Mikulčić, Raznocarski skeletni grobovi iz Skupa, Starinar N.S., 24-25. 1973-1974 (1975), p. 89-102.

Moga et alii 2003 - V. Moga, C. Inel, A. Gligor, A. Dragotă, Necropola de incinerafie din Functıl Hop, în Alburnus Maior I, 2003, p. 193-251.

Neagu, Bocan 2007-2008 - Cătălina-Mihaela Neagu, Ionu\} Bocan, Consideratii preliminare cisnpro unei incinte funerare din necropola romană de incineratie de la Tăul Secuilor-Pâriàl Porcuitri, CercA, XIV-XV, 2007-2008, p. 93-122.

Ortalli 1998 - J. Ortalli, Riti, usi e corredi funerari nelle sepolture romane della frima eid imperialc in Emilia Romagna (valle del Po), Bestattungssitte und Kulturelle Identität. Grabanlagen und Grabbeigaben der frühen Römischen Kaiserzeit in Italien und den Nordwest-Provinzen. Kolloquium in Xanten vom 16 bis 18 Februar 1995. Römische Gräber des I Jhs. n. Chr. in Italien und Nordwestprovinzen, Xanten, 1998, p. 49-86.

Petrovsky 1979 - R. Petrovsky, Tipuri de morminte romane in zona Caransebc'sului, Barıtica, 5, 1979, $p$. $201-213$.

Protasc 1974 - D. Protase, Necropola orașului Atulum. Săpăturile din anii 1970-197I, Apu'L.m, 12, 1974, p. $134-159$.

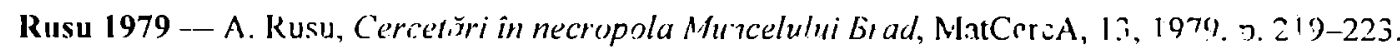

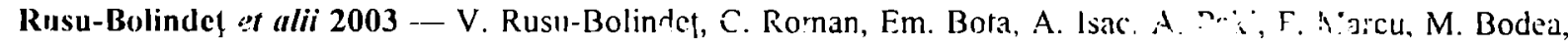
Firme de habitat in punciul Balea, în Albu:mus Maicr, I, p. 387-431. 
Schucany $2000-$ C. Schucany, An elite funerary enclosure in the centre of the villa of Biberist-Spitalhof (Switzerland) - a case of study, în Burial, Society and Context in the Roman World, Oxford, 2000, p. 118-126. Simion et alii 2004 - M. Simion, V. Apostol, D. Vleja, Monumenul funerar circular, Albumus Maior, II, 2004. Srcjović 1965 - D. Srejović, Rinske Nekropole panog Harstra i Jugoslaviji, Starinar N.S., 13-14, 1962-1963 (1965), p. 49-88.

Topál 1993 - J. Topál, Roman cemeteries of Aquincum, Pannonia, The Western Cemetery in Bécsi Road I, Budapesta. 1993.

Topal 2000 - J. Topál, The connection between funerary rites and ethnic groups in the cemeteries of northeastern Pannonia, în Burial, Society and Context in the Roman World, Oxford, 2000, p. 197-203.

Zotović 1968 - Lj. Zotović, Nekropole spaljenih pokojnika na teritoriji Gornje Mesije, Leskovački Zbornik, 8, 1968, p. 19-30.

Zotović, Jordović 1990 - Lj. Zotović, Č. Jordović, Viminacium I, Nekropola Više Grobalja, Beograd, 1990.

\section{LISTA ILUSTRATIEI}

PI. 1 - Roşia Montană, necropola de incineraţie de la Tăul Găuri-Hop, plan general apud Simion et alii 2004.

PI. 2 - Roşia Montană, necropola de incineraţie de la Tăul Găuri-Hop, plan general al incintei funerare.

PI. 3-Roşia Montană, necropola de incineraţie de la Tăul Găuri-Hop, stratigrafie internă a incintei funerare.

PI. 4 - Roşia Montană, necropola de incineraţie de la Tăul Găuri-Hop, M 29, plan şi profil.

PI. 5 - Roşia Montană, necropola de incineraţie de la Tăul Găuri-Hop, M 29, inventar funerar.

PI. 6-Roşia Montană, necropola de incineraţie de la Tăul Găuri-Hop, M 30, plan şi profil.

PI. 7 - Roşia Montană, necropola de incineraţie de la Tăul Găuri-Hop, M30, inventar funerar.

PI. 8-Roşia Montană, necropola de incineraţie de la Tăul Găuri-Hop, M30, inventar funerar.

PI. 9 - Roşia Montană, necropola de incineraţie de la Tăul Găuri-Hop, M 31, plan şi profil.

PI. 10 - Roşia Montană, necropola de incineraţie de la Tăul Găuri-Hop, M3 I, inventar funerar.

PI. 11 - Roşia Montană, necropola de incineraţie de la Tăul Găuri-Hop, M31, inventar funerar.

PI. 12 - Roşia Montană, necropola de incineraţie de la Tăul Găuri-Hop, M 32, plan şi profil.

PI. 13 - Roşia Montană. necropola de incineraţie de la Tăul Găuri-Hop, inventar incintă.

PI. 14 - Roşia Montană, necropola de incineraţie de la Tăul Găuri-Hop, inventar incintă.

Pl. 15 - Roşia Montană, necropola de incineraţie de la Tăul Găuri-Hop, inventar incintă.

Pl. 16 - Roşia Montană, necropola de incineraţie de la Tăul Găuri-Hop, inventar incintă.

\section{ILUSTRATION LIST}

Pl. 1 -- Roşia Montană, Tăul Găuri-Hop cremation necropolis, general plan apud Simion et alii 2004.

Pl. 2 - Roşia Montană, Tăul Găuri-Hop cremation necropolis, general plan of the funerary enclosure.

PI. 3 - Roşia Montană, Tăul Găuri-Hlop cremation necropolis, inner stratigraphy of the funerary enclosure.

PI. 4 -- Roşia Montană, Tăul Găuri-Hop cremation necropolis, Grave 29, plan and profile.

PI. 5 - Roşia Montană, Tăul Găuri-Hop cremation necropolis, Grave 29, funerary inventory.

PI. 6 - Roşia Montană, Tăul Găuri-Hop cremation necropolis, Grave 30, plan and profile.

PI. 7 - Roşia Montană, Tăul Găuri-Hop cremation necropolis, Grave 30, funerary inventory.

PI. 8 - Roşia Montană, Tăul Găuri-Hop cremation necropolis, Grave 30, funerary inventory.

P'. 9 -- Roşia Montană, Tăul Găuri-Hop cremation necropolis, Grave 31, plan and profile.

PI. 10 - Roşia Montană, Tăul Găuri-Hop cremation necropolis, Grave 31, funerary inventory.

PI. 11 - Roşia Montană, Tăul Găuri-Hop cremation necropolis, Grave 31, funerary inventory.

PI. 12 - Roşia Montană, Tăul Găuri-Hop cremation necropolis, Grave 32, plan and profile.

Pl. 13 - Roşia Montană, Tăul Găuri-Hop cremation necropolis, enclosure's inventory.

PI. 14 - Roşia Montană, Tăul Găuri-Hop cremation necropolis, enclosure's inventory. 
Pl. 15 - Roşia Montană, Tăul Găuri-Hop cremation necropolis, enclosure's inventory.

Pl. 16 - Roşia Montană, Tăul Găuri-Hop cremation necropolis, enclosure's inventory.

\section{PRELUCRARE ILUSTRATIE}

Călălina-Mihaela Neagu

Daniela Iacovache

\section{DESENE PIESE:}

Georgiana Ducman, Simona Movilă

\section{IONUT BOCAN}

\section{CÃTĂLINA-MIHAELA NEAGU}

\section{EMIL IONUT DUMITRAŞCU}

Muzeul Naţional de Istorie a României, Calea Victoriei, nr. 12, sector 3, 030026

Bucureşti ionutzbocan@gmail.com catalina_mihaela_n@yahoo.com emildumitrascuionut@gmail.com

\section{GABRIEL BĂLAN}

Muzeul Naţional al Unirii Alba Iulia Mihai Viteazul, nr: 12-14, 510010 Alba Iulia

liviugabrielbalan@yahoo.com 


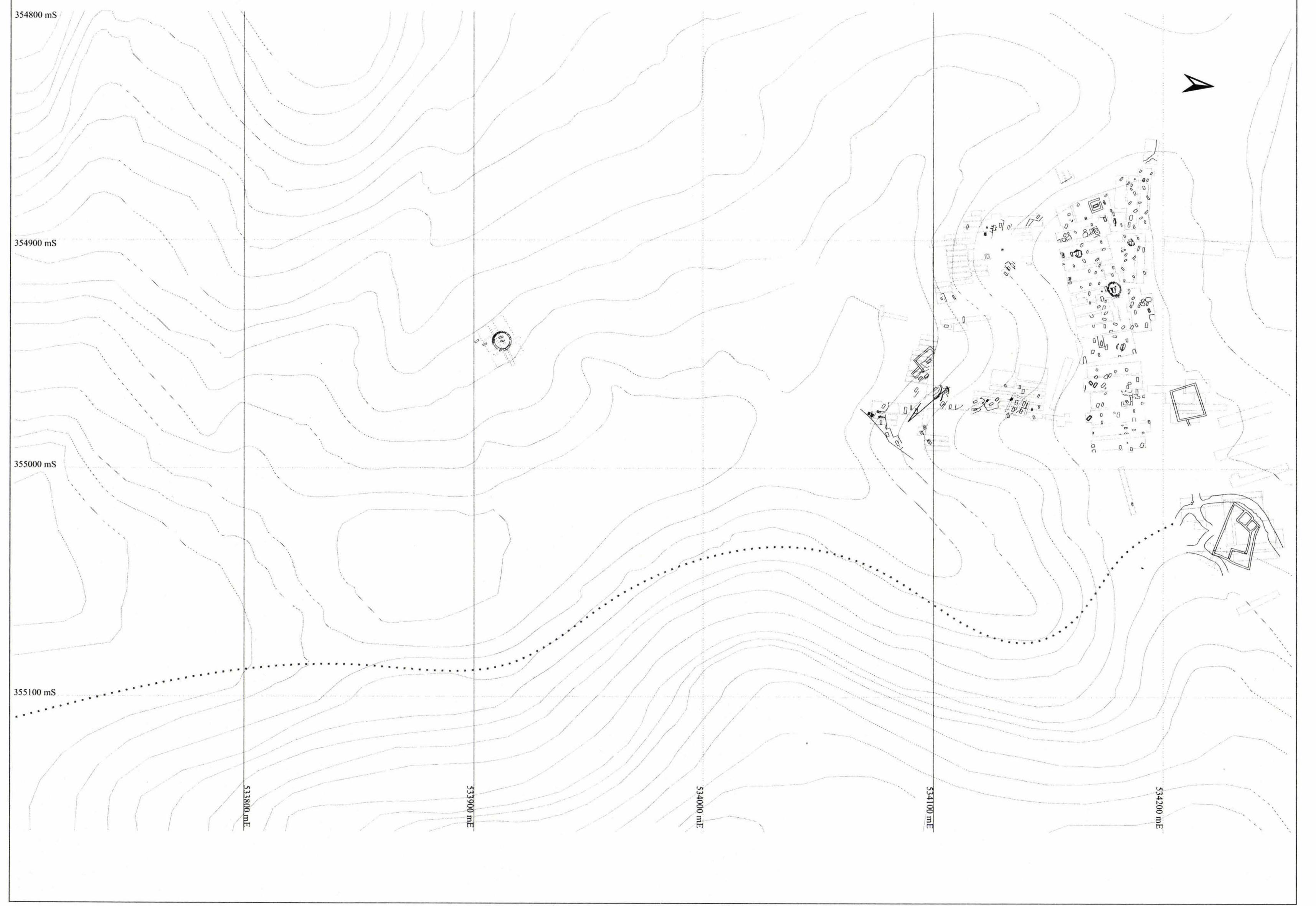

Pl.1 - Plan general al necropolei (apud Simion et alii 2004) 


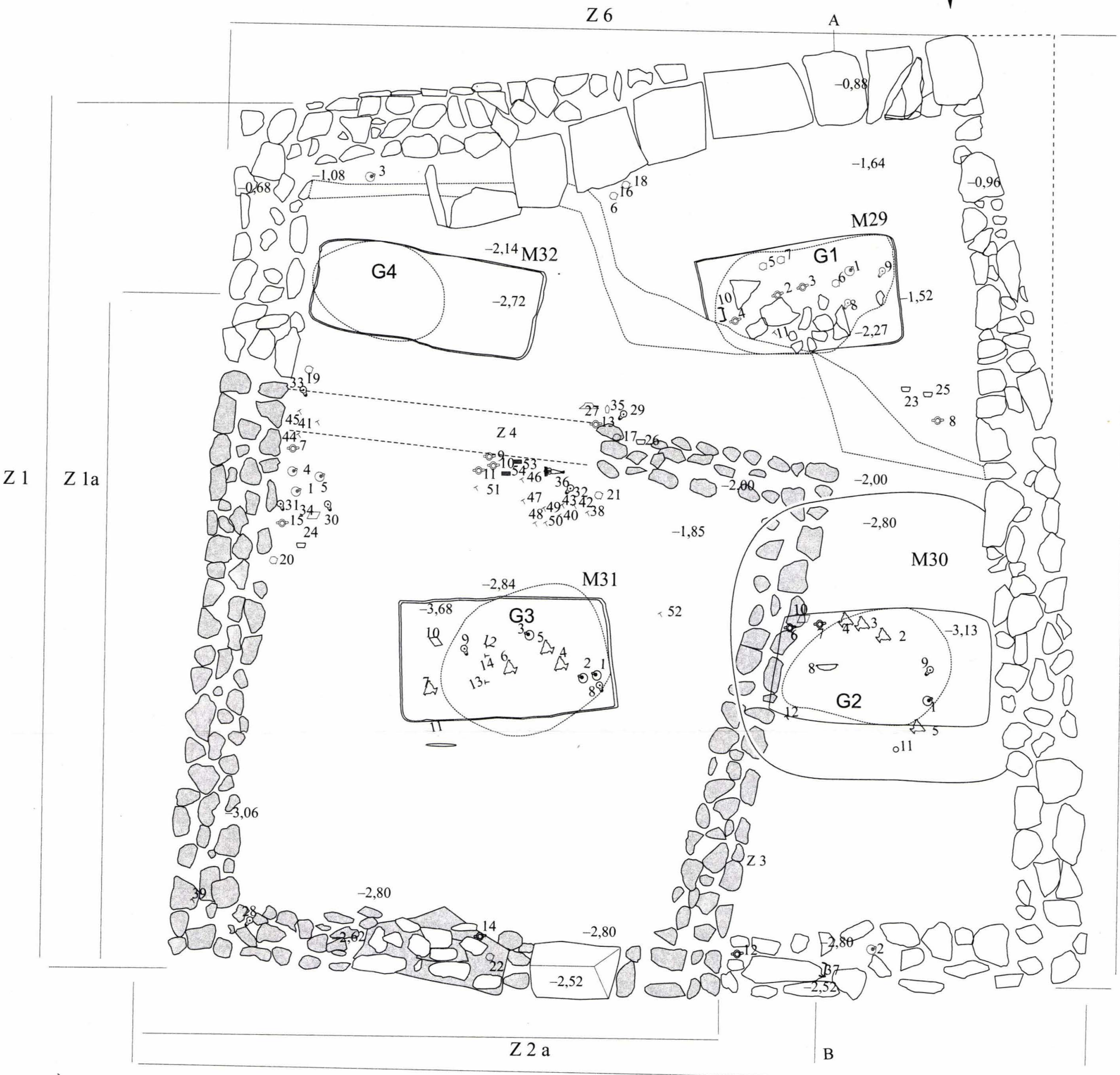

Z 2

\section{Legendă:}

\begin{tabular}{|c|c|c|c|}
\hline$\square$ & Blocuri de piatră din faza I de construcţie a incintei & $\square$ & Cupă/bol \\
\hline 0 & Blocuri de piatră din faza II de construcție a incintei & $\smile$ & Farfurie \\
\hline$\theta$ & Chaperon & 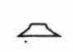 & Capac \\
\hline a & Bază monument funerar & 8 & Opaiţ \\
\hline & Conturul gropilor sepulcrale & $\square$ & Vas nedeterminabil ca formă \\
\hline .... & Conturul gropilor de intervenţie & ० & Monedă \\
\hline అ & Urcior & 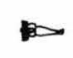 & Fibulă \\
\hline ए & Turibulum & $\uparrow$ & Scoabă \\
\hline$\infty$ & Oală & 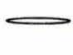 & Element de îmbinare \\
\hline \multirow[t]{3}{*}{0} & Cupă & $\vdash$ & Piron/ţintă \\
\hline & & & Obiect neidentificat \\
\hline & & 0 & Cuarţ \\
\hline
\end{tabular}




\section{Legendă:} Sol vegetal de culoare cenuşie
(orizontul organic al solului actual)

2] Nivel de argilă siltică de culoare brun-negriciosă

3 Nivel de argilă siltică de culoare galbenă

4. Stâncă nativă

[5] Nivel nisipos negricios

(umplutura şanţului de fundaţie a zidurilor $\mathbf{Z 1}$ şi $\mathbf{Z 5}$ )

Zid $\square$ Sol ars de culoare cărămizie

- Nivel de reziduuri ale cremaţiei

6 Sediment de umplutură al gropilor

sepulcrale de culoare galben-maronie

Sediment de umplutură al gropilor de intervenție

de culoare cenuşiu-negricios

0

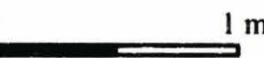



M 29
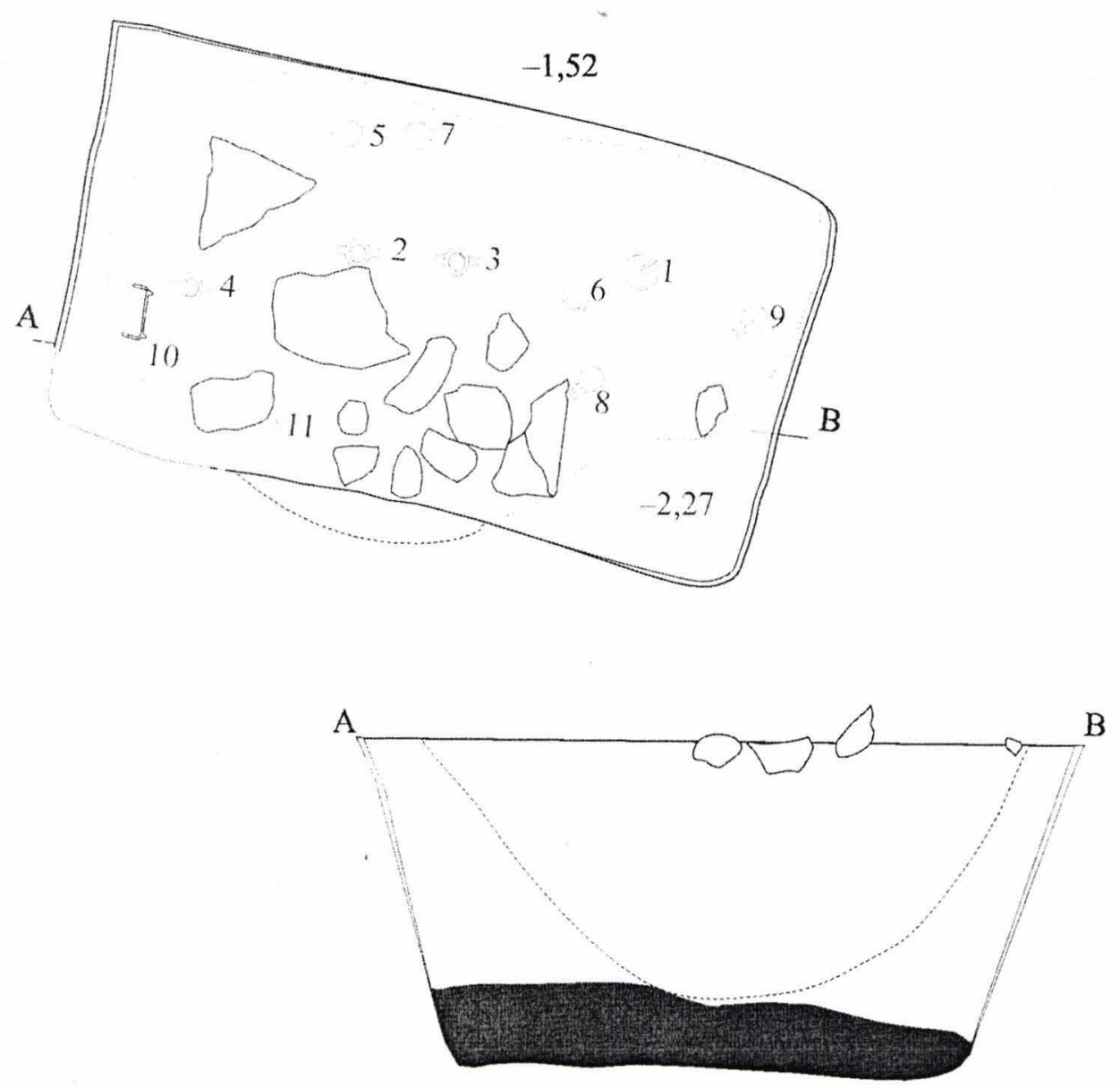

0 $0,5 \mathrm{~m}$

Legendă:

Conturul gropilor sepulcrale

Conturul perturbărilor

Nivel de reziduuri ale cremaţiei

[] Pietre

Urcior
- Oală

- Cupă

- Opaiţ

^ Scoabă

$\vdash$ Piron/ţintă

PI. 4-M 29, plan şi profil 


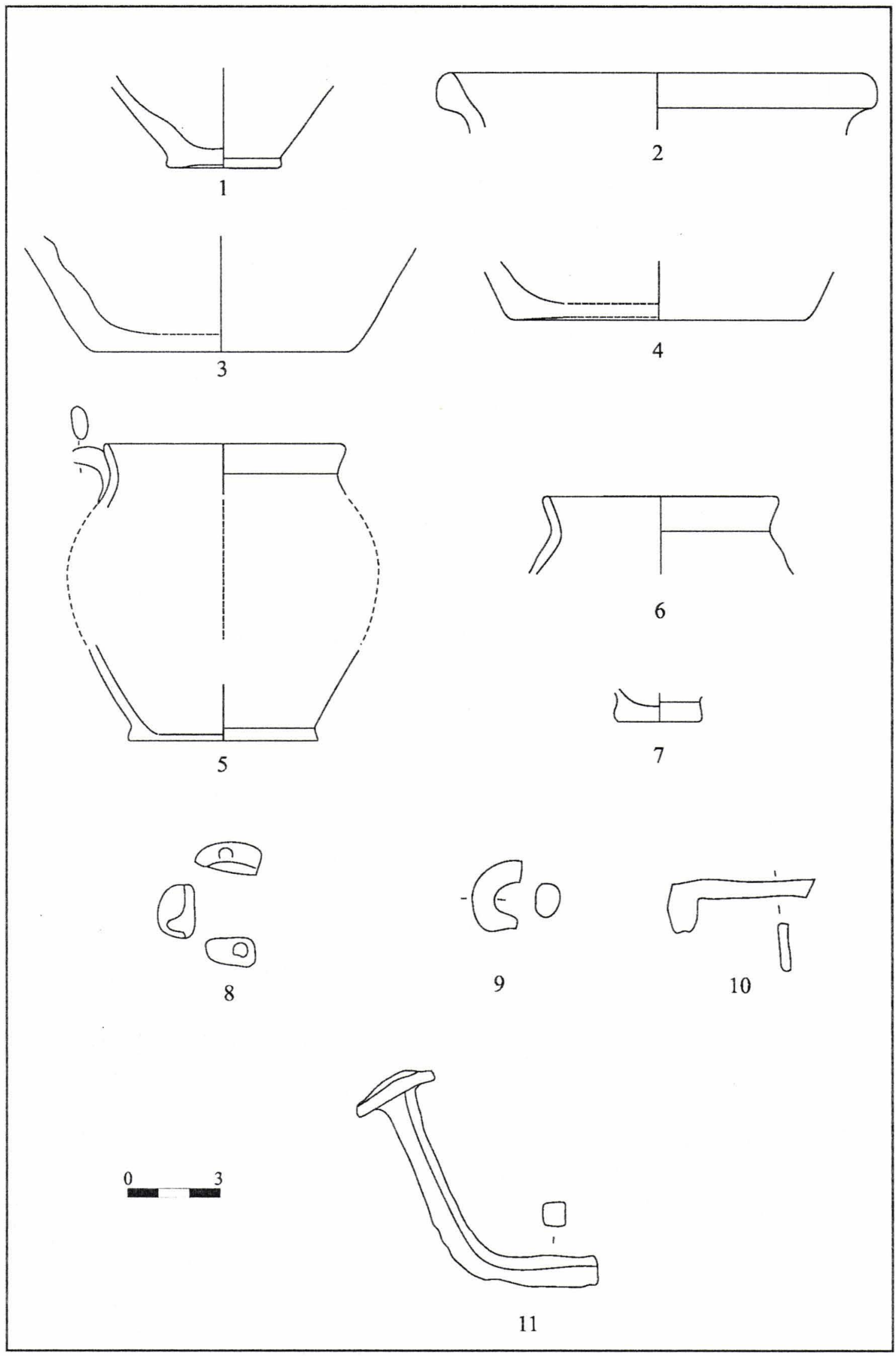

Pl. 5 - M 29, inventar funerar 
M 30

$-2,00$

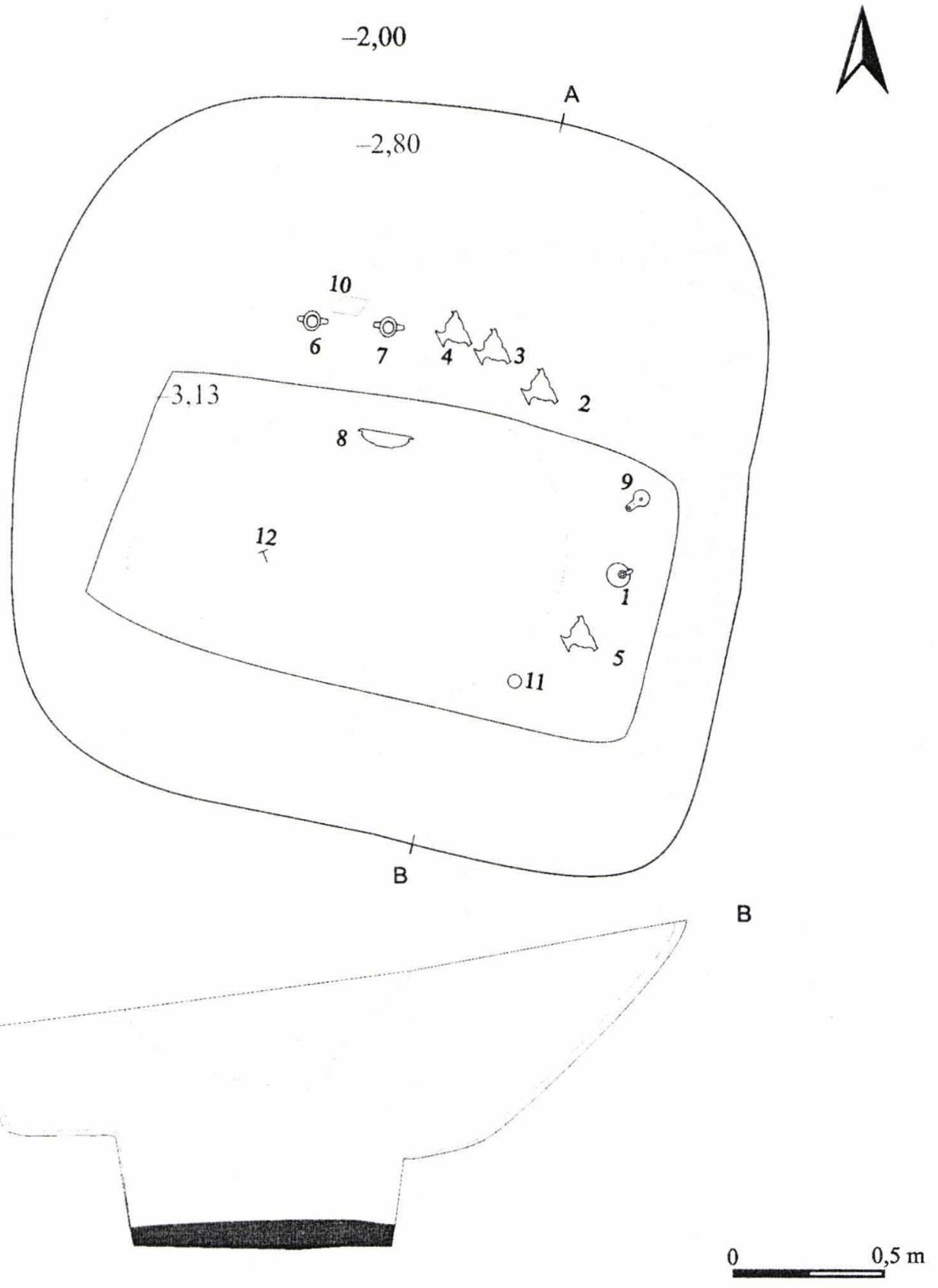

$\lambda$

B

A

Legendă:

Conturul gropilor sepulcrale

$\smile$ Farfurie

Conturul perturbărilor

- Opaiţ

= Nivel de reziduuri ale cremaţiei

(थ) Urcior

¿ Turibulum

$\square$ Vas nedeterminabil ca formă

- Monedă

$\vdash$ Piron/ţintă

- Oală

Pl. 6-M 30, plan şi profil 

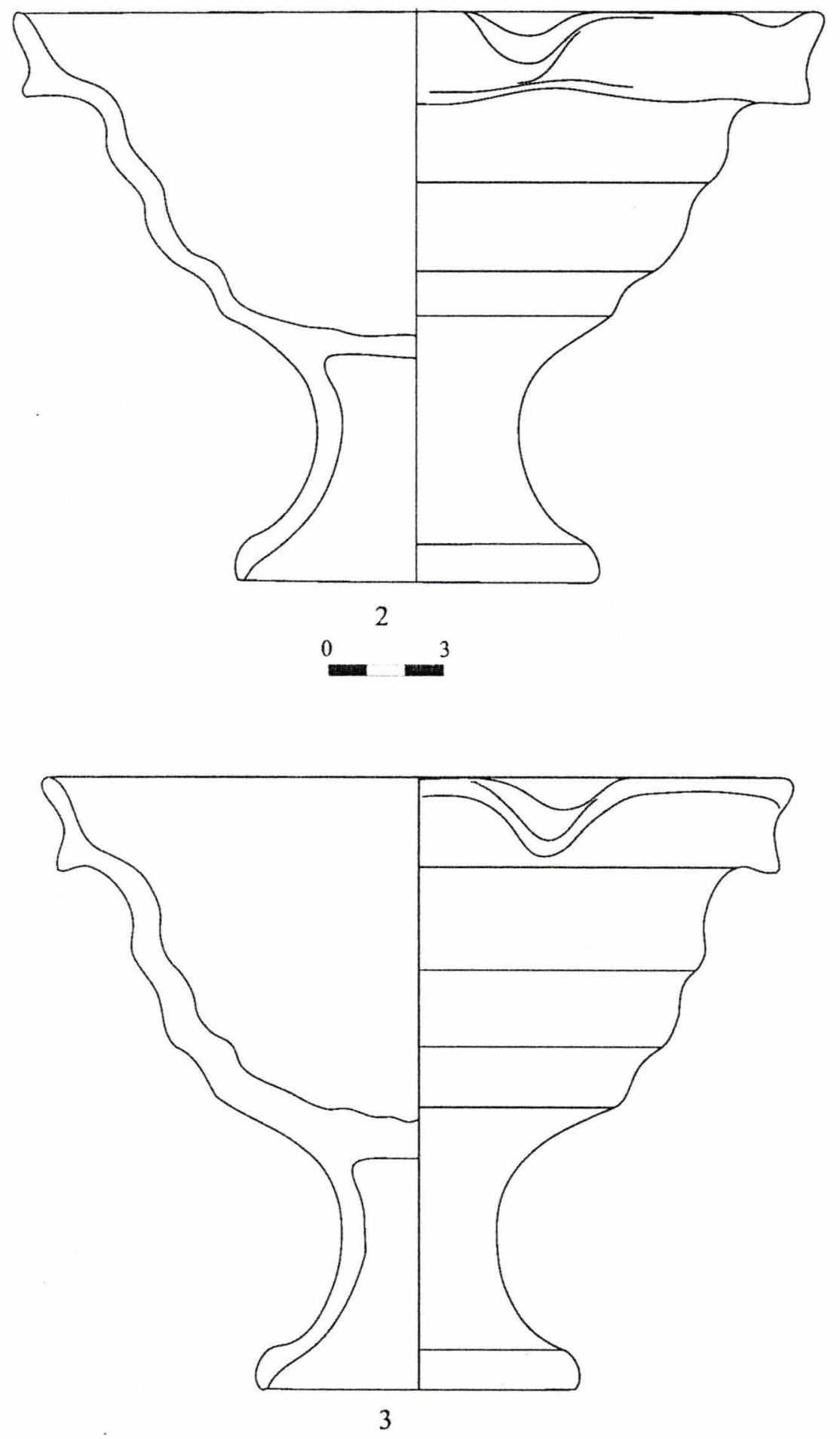

PI. 7 - M 30, inventar funerar 

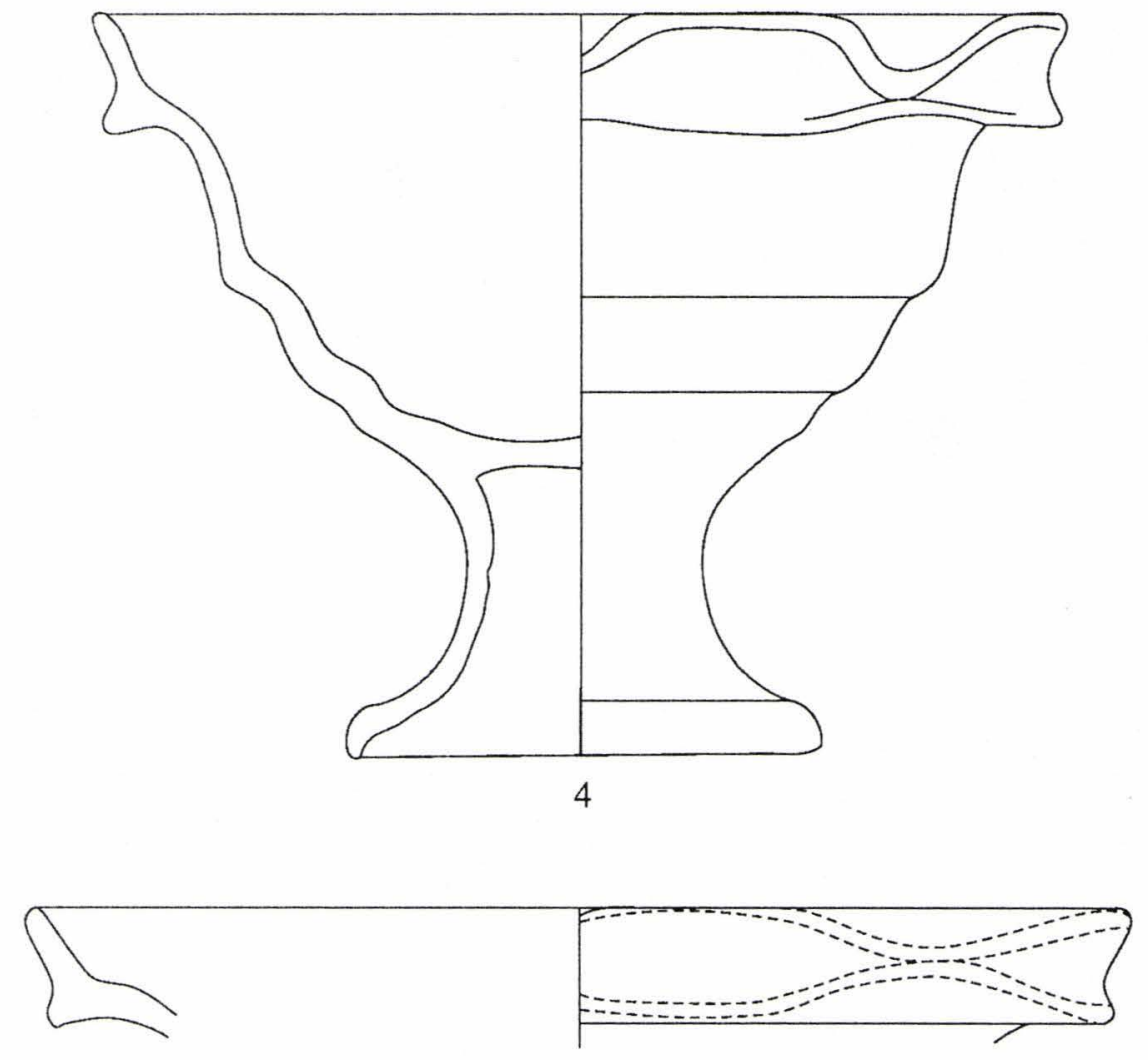

5
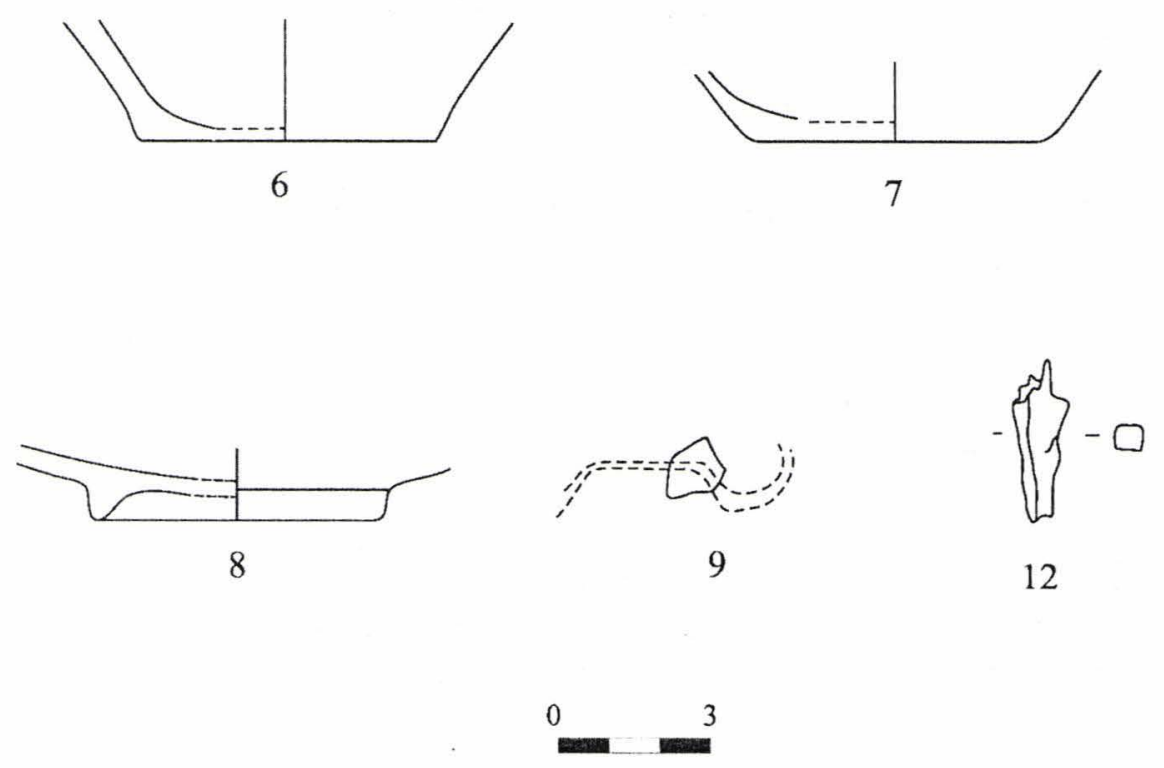

PI. 8 - M 30, inventar funerar 
M 31

$-2,84$
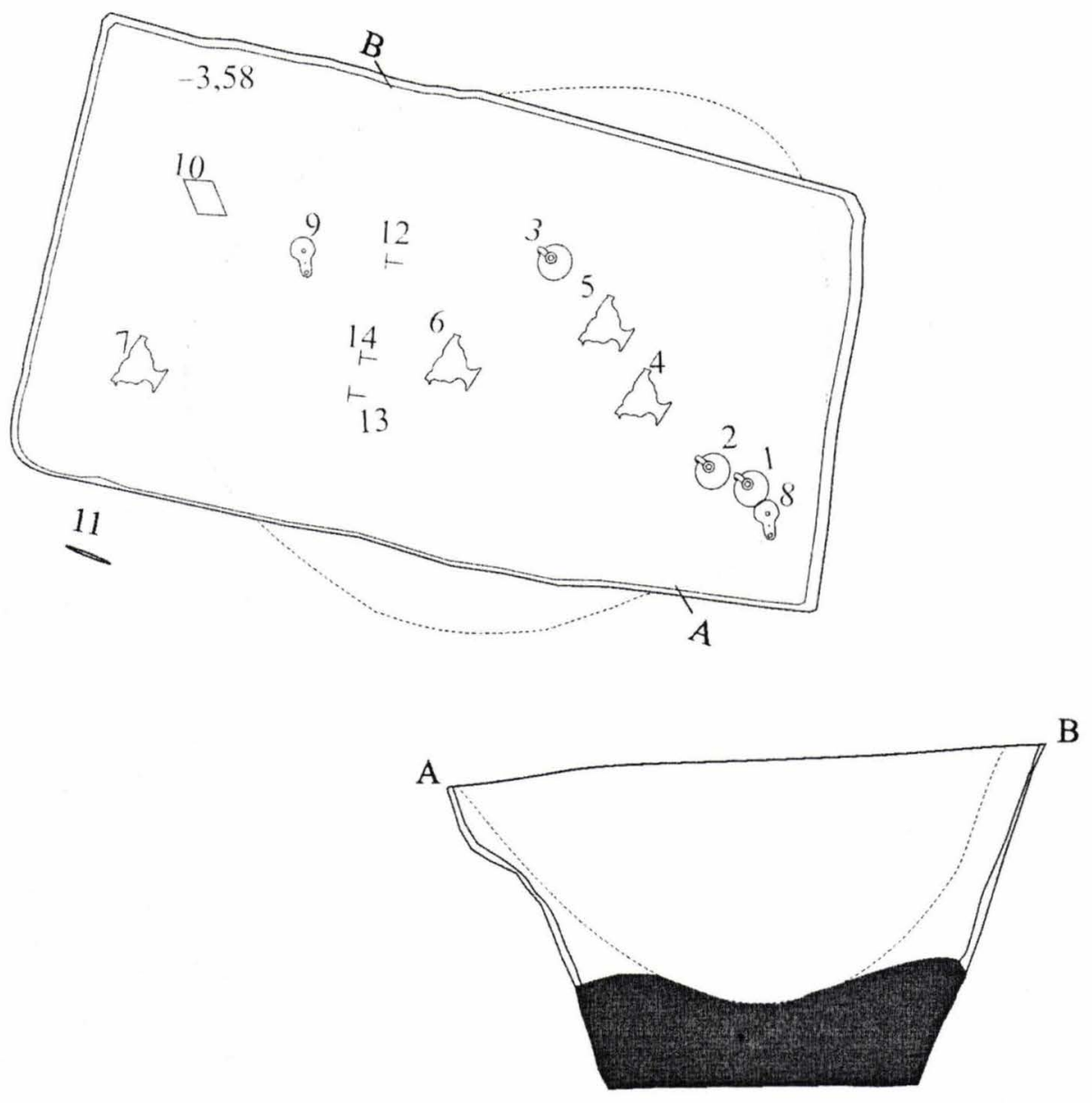

0 $0,5 \mathrm{~m}$

\section{Legendă:}

Conturul gropilor sepulcrale

Conturul perturbărilor

- Nivel de reziduuri ale cremaţiei

๑rcior

I) Turibulum
D. Opaiţ

$\square$ Vas nedeterminabil ca formă

- Element de îmbinare

r Piron/ţintă

PI. 9-M 31, plan şi profil 

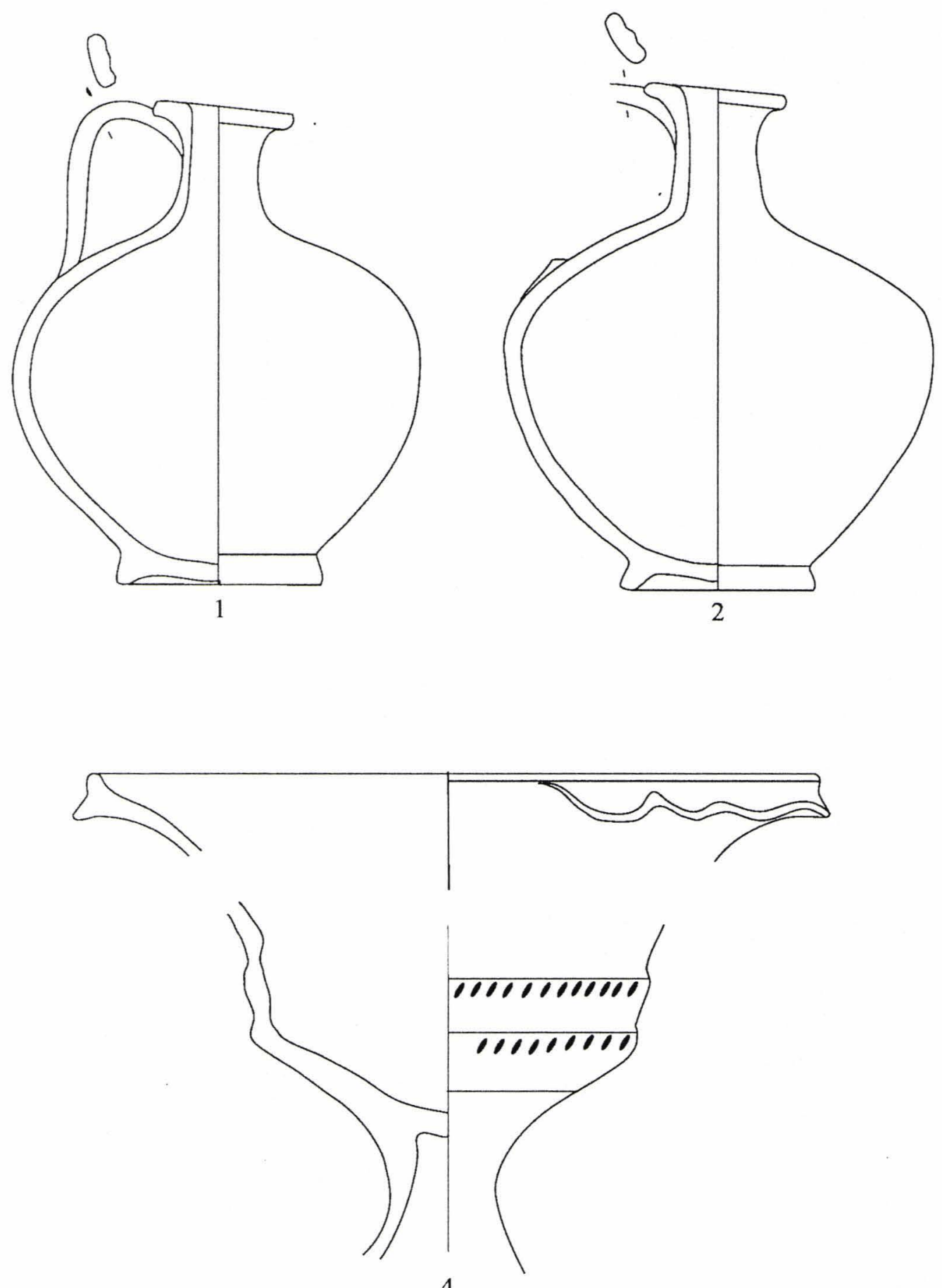

4

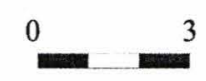

Pl. 10 - M 31, inventar funerar 


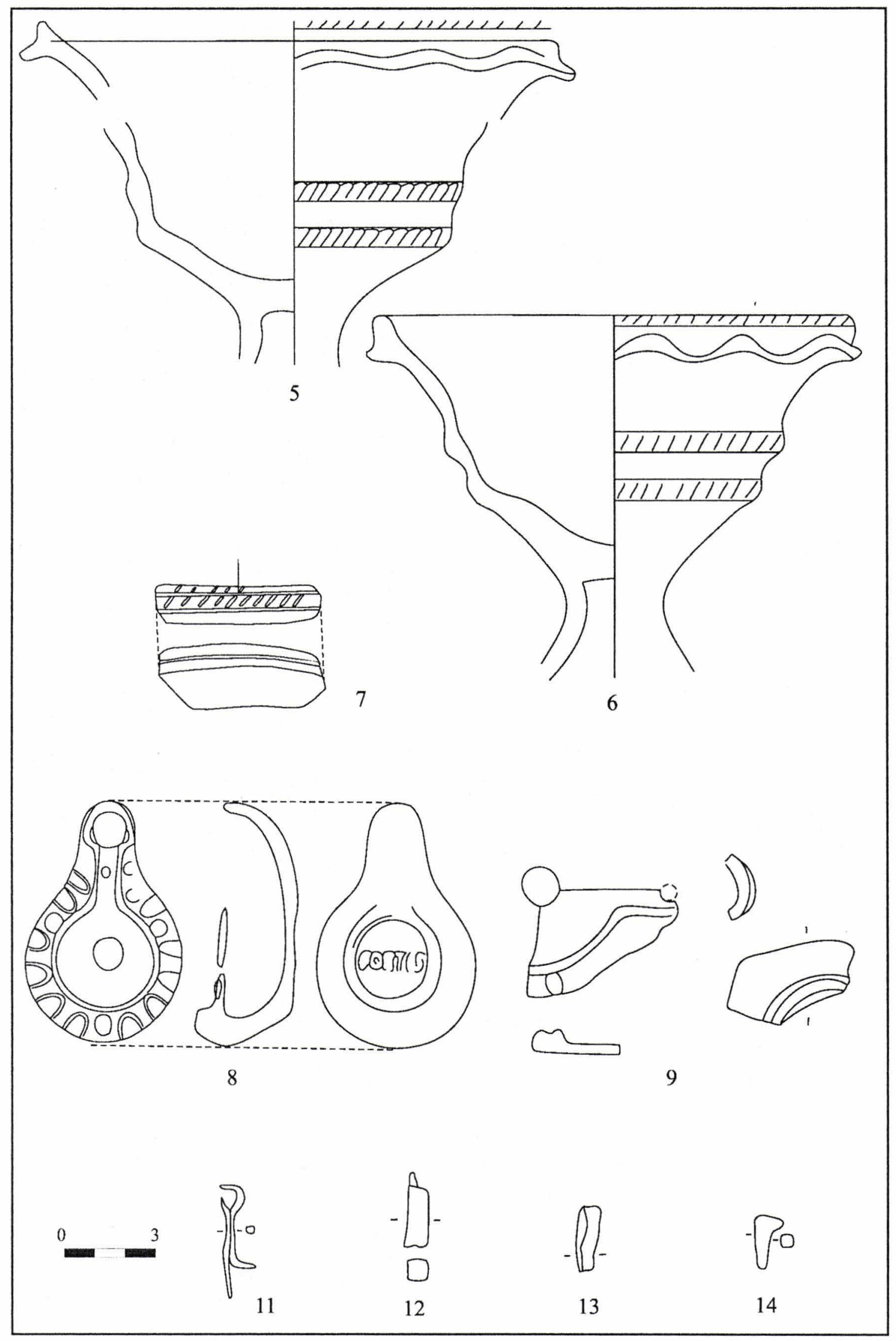

Pl. 11 - M 31, inventar funerar 
M 32
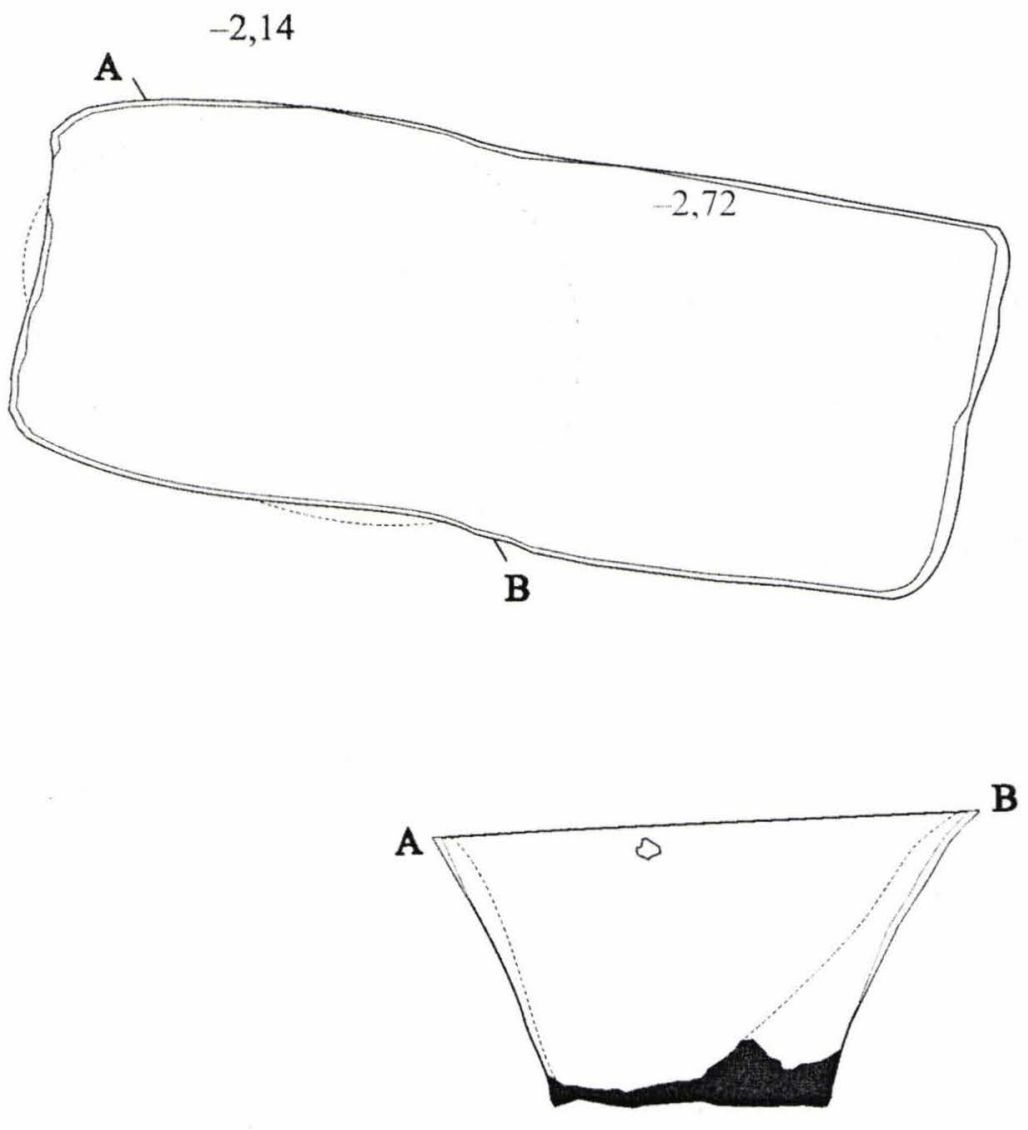

$0,5 \mathrm{~m}$

Legendă:

Conturul gropilor sepulcrale

Conturul perturbărilor

Nivel de reziduuri ale cremaţiei

Pl. 12 - M 32, plan şi profil 


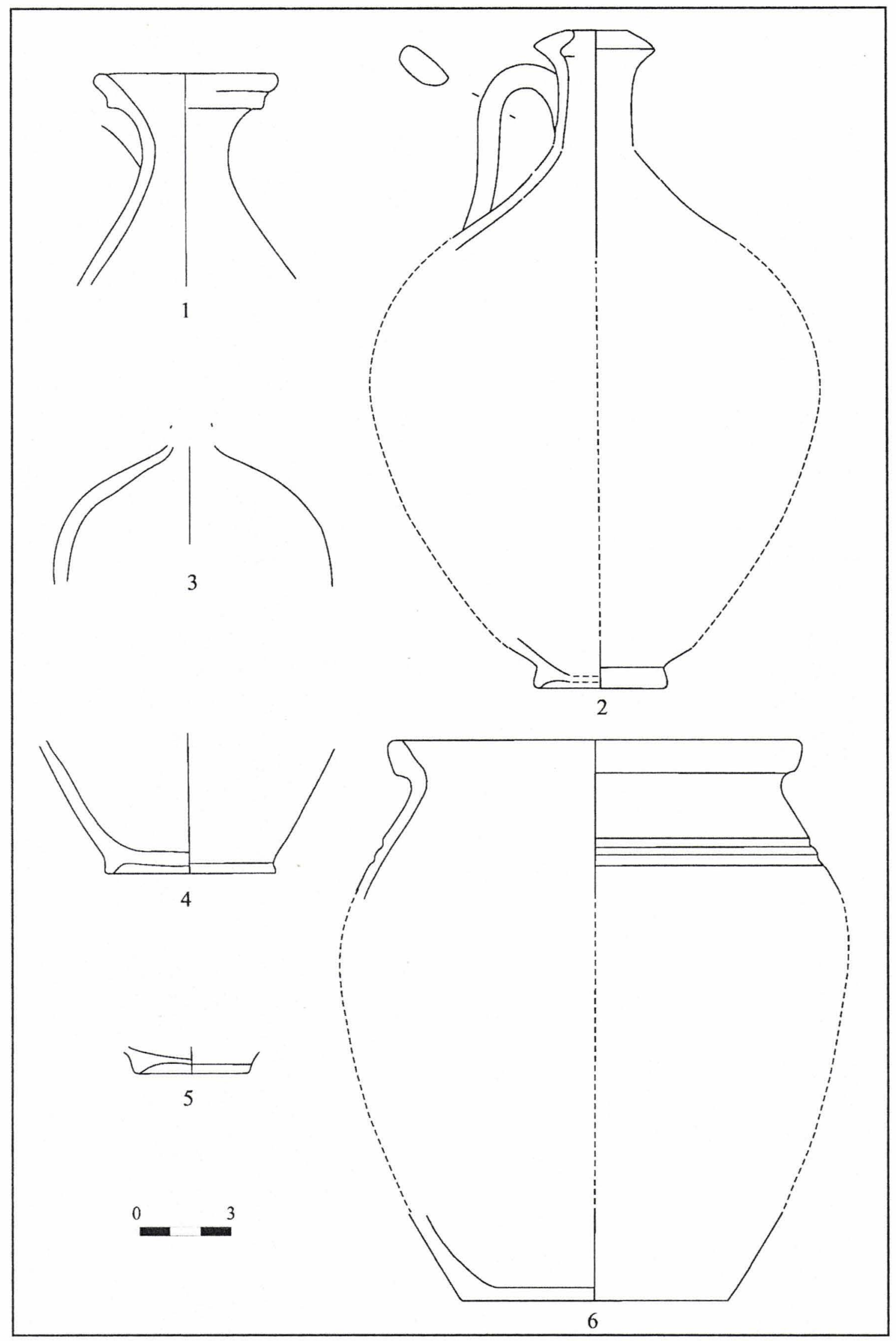

PI. 13 - Inventar incintă 


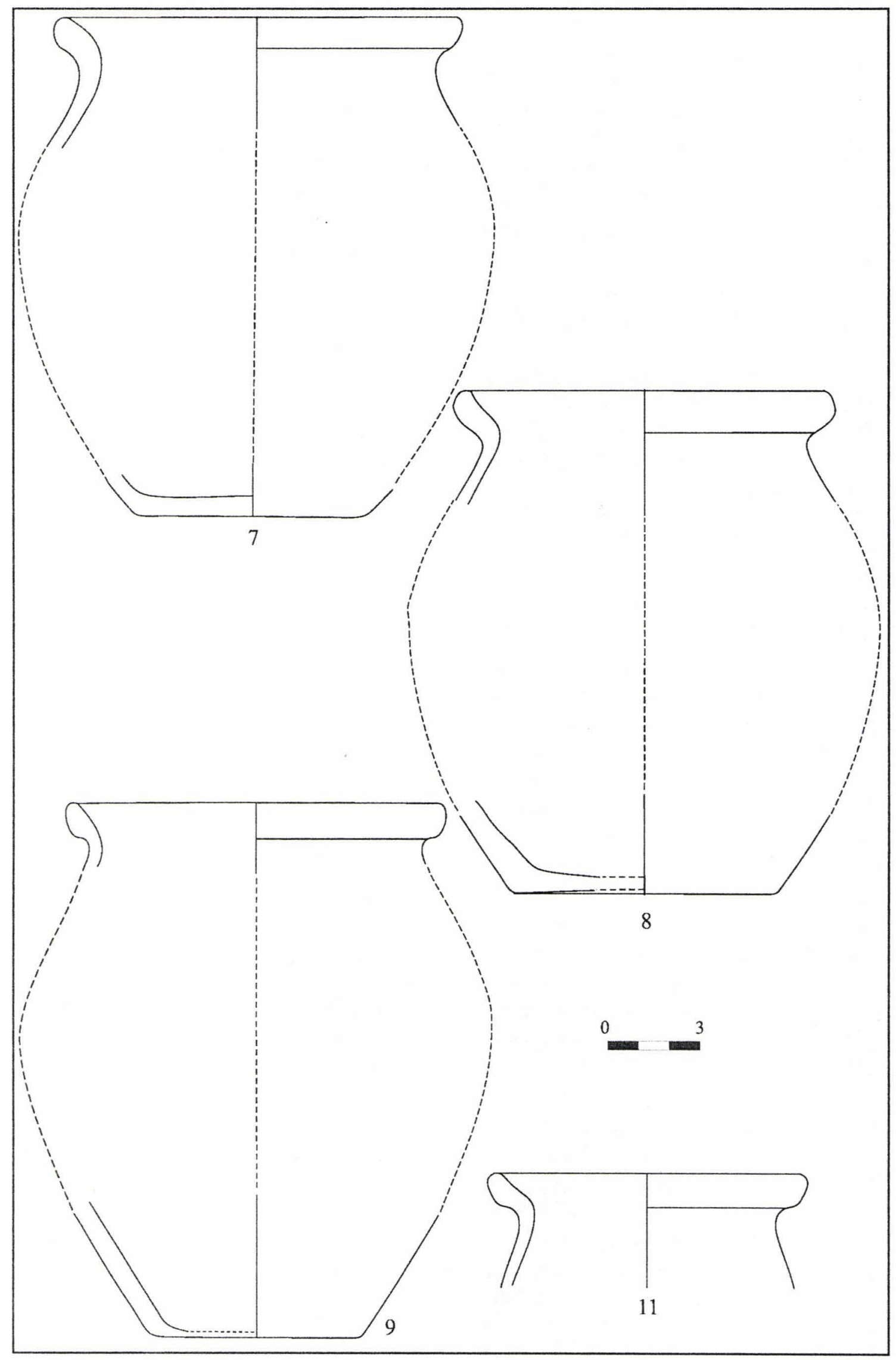

PI. 14 - Inventar incintă 


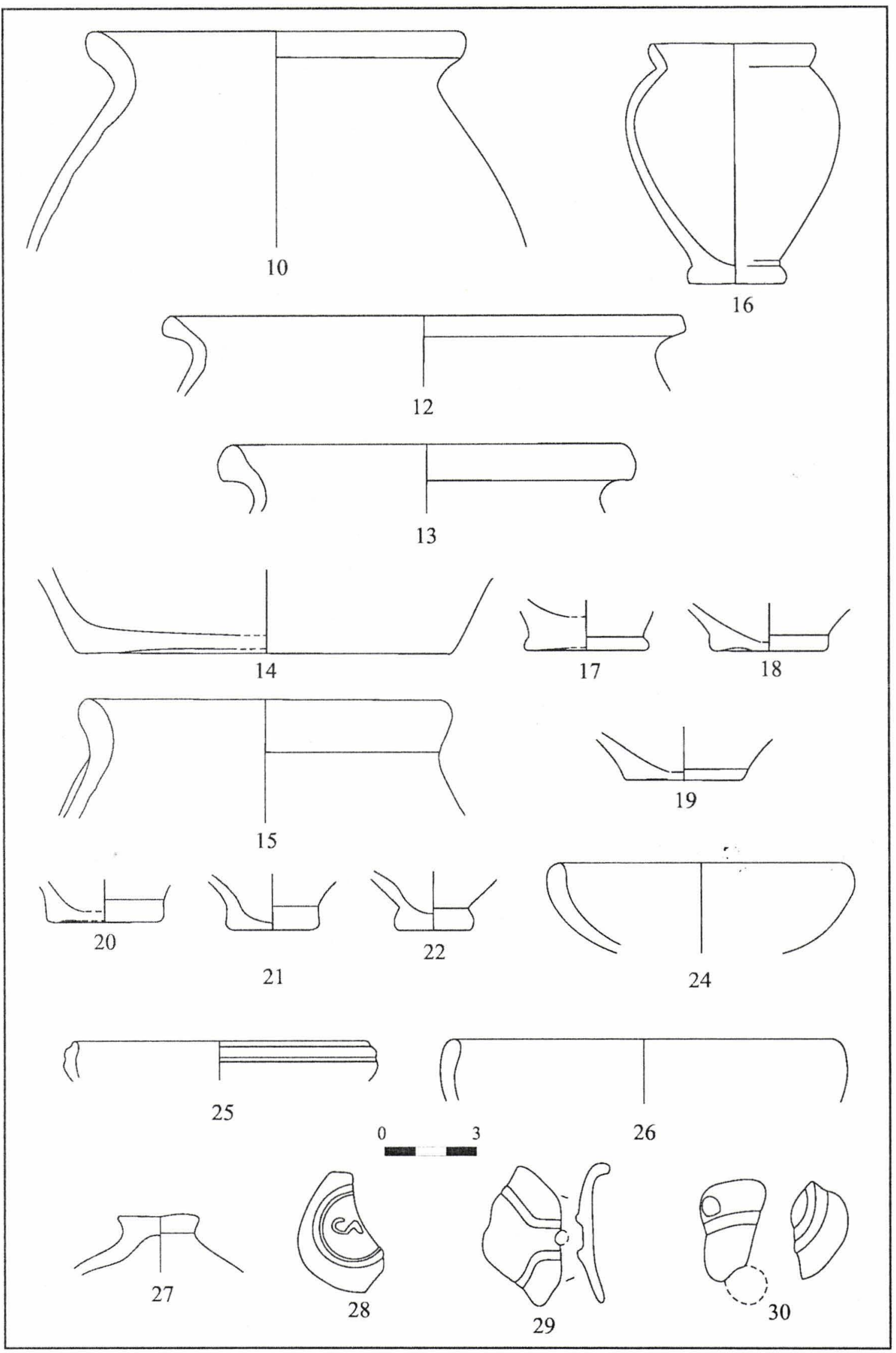

Pl. 15 - Inventar incintă 

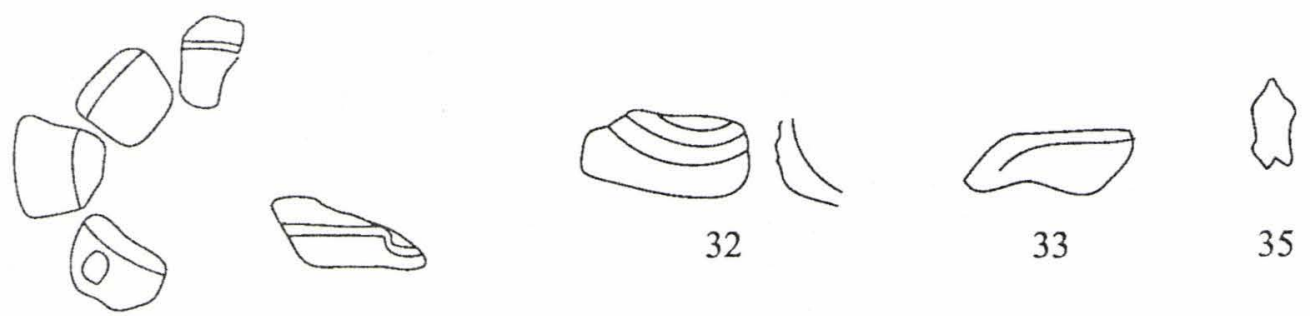

31
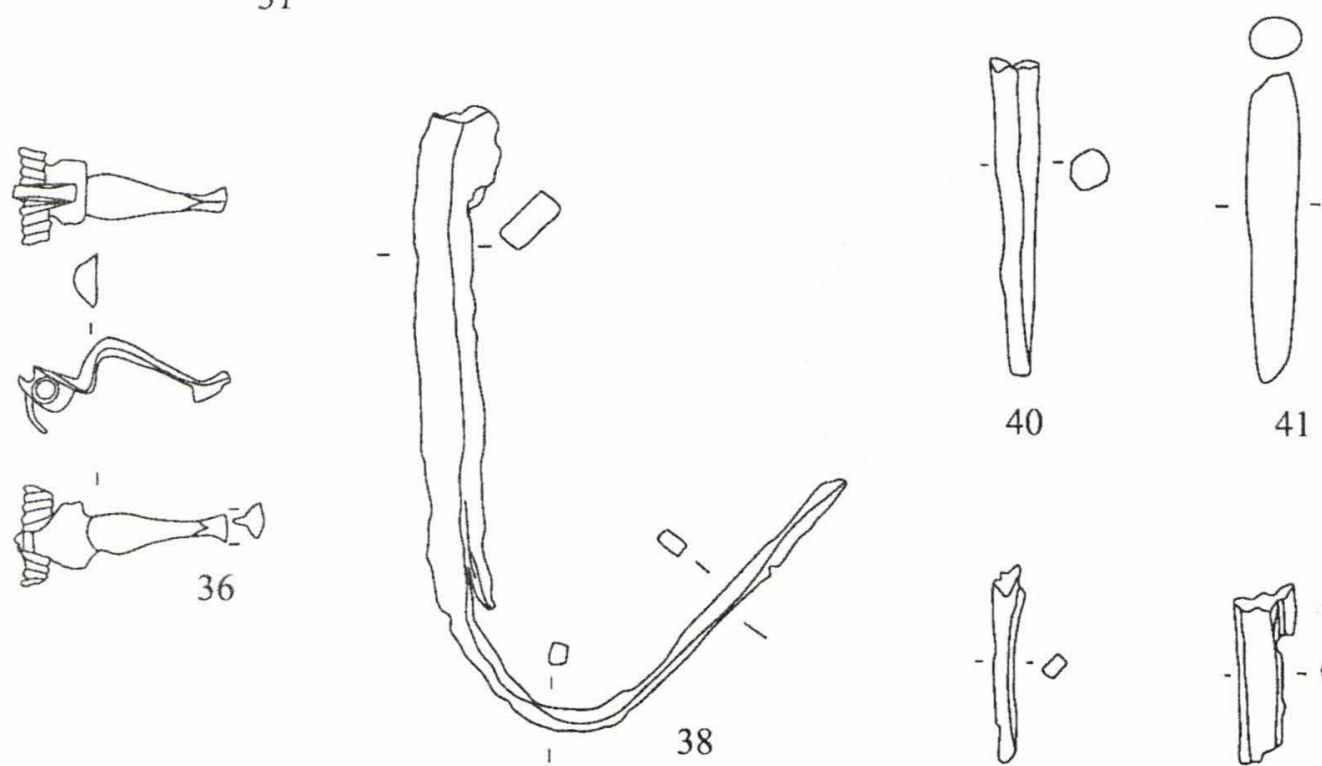

40

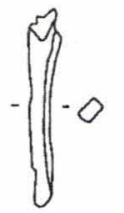

42

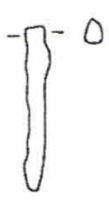

44

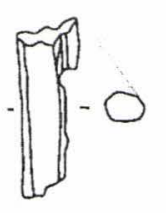

43

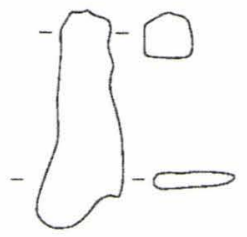

37

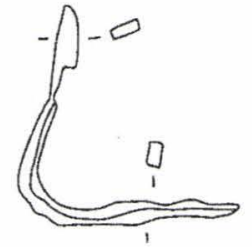

39

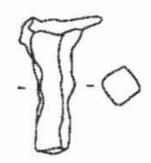

48

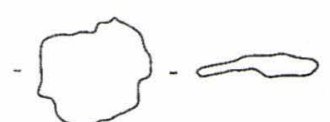

$-\int-\infty$

49 $-\sqrt{10}-0$

50

$[0,1]-]$

Pl. 16 - Inventar incintă 
